\title{
Phosphorylation of HIV-I Tat by CDK2 in HIV-I transcription
}

\author{
Tatyana Ammosova1, Reem Berro4, Marina Jerebtsova5, Angela Jackson², \\ Sharroya Charles ${ }^{3}$, Zachary Klase ${ }^{4}$, William Southerland ${ }^{2}$, Victor R Gordeuk ${ }^{1}$, \\ Fatah Kashanchi ${ }^{4}$ and Sergei Nekhai*1,2,4
}

\begin{abstract}
Address: ${ }^{1}$ Center for Sickle Cell Disease, Howard University College of Medicine, 520 W Street N.W., Washington, DC 20059, USA, ${ }^{2}$ Departmen of Biochemistry and Molecular Biology, Howard University College of Medicine, 520 W Street N.W., Washington, DC 20059, USA, 3 Program in Genetics, Howard University College of Medicine, 520 W Street N.W., Washington, DC 20059, USA, ${ }^{4}$ Department of Biochemistry and Molecular Biology, The George Washington University Medical Center, 2300 I Street N.W., Washington, DC 20037, USA and ${ }^{5}$ Children's National Medical Center, CRI Center III, 111 Michigan Ave., N.W. Washington, D.C. 20010-2970, USA

Email: Tatyana Ammosova - tammosova@mail.ru; Reem Berro - ramroom@gmail.com; Marina Jerebtsova - mjerebts@cnmc.org; Angela Jackson - comptona99@hotmail.com; Sharroya Charles - sho2roya@yahoo.com; Zachary Klase - zklase@gwu.edu; William Southerland - wsoutherland@howard.edu; Victor R Gordeuk - vgoreduk@howard.edu; Fatah Kashanchi - bcmfxk@gwumc.edu; Sergei Nekhai* - snekhai@howard.edu

* Corresponding author
\end{abstract}

Published: 03 November 2006

Retrovirology 2006, 3:78 doi:10.1186/1742-4690-3-78

This article is available from: http://www.retrovirology.com/content/3/I/78

(C) 2006 Ammosova et al; licensee BioMed Central Ltd.

This is an Open Access article distributed under the terms of the Creative Commons Attribution License (http://creativecommons.org/licenses/by/2.0), which permits unrestricted use, distribution, and reproduction in any medium, provided the original work is properly cited.

\begin{abstract}
Background: Transcription of HIV-I genes is activated by HIV-I Tat protein, which induces phosphorylation of RNA polymerase II (RNAPII) C-terminal domain (CTD) by CDK9/cyclin TI. Earlier we showed that CDK2/cyclin E phosphorylates HIV-I Tat in vitro. We also showed that CDK2 induces HIV-I transcription in vitro and that inhibition of CDK2 expression by RNA interference inhibits HIV-I transcription and viral replication in cultured cells. In the present study, we analyzed whether Tat is phosphorylated in cultured cells by CDK2 and whether Tat phosphorylation has a regulatory effect on HIV-I transcription.

Results: We analyzed HIV-I Tat phosphorylation by CDK2 in vitro and identified Ser ${ }^{16}$ and Ser ${ }^{46}$ residues of Tat as potential phosphorylation sites. Tat was phosphorylated in HeLa cells infected with Tat-expressing adenovirus and metabolically labeled with ${ }^{32} \mathrm{P}$. CDK2-specific siRNA reduced the amount and the activity of cellular CDK2 and significantly decreased phosphorylation of Tat. Tat co-migrated with CDK2 on glycerol gradient and co-immunoprecipitated with CDK2 from the cellular extracts. Tat was phosphorylated on serine residues in vivo, and mutations of Ser ${ }^{16}$ and Ser ${ }^{46}$ residues of Tat reduced Tat phosphorylation in vivo. Mutation of Ser ${ }^{16}$ and Ser ${ }^{46}$ residues of Tat reduced HIV-I transcription in transiently transfected cells. The mutations of Tat also inhibited HIV-I viral replication and Tat phosphorylation in the context of the integrated HIV-I provirus. Analysis of physiological importance of the $\mathrm{S}^{16} \mathrm{QP}(\mathrm{K} / \mathrm{R})^{19}$ and $\mathrm{S}^{46} \mathrm{YGR} \mathrm{R}^{49}$ sequences of Tat showed that Ser ${ }^{16}$ and $\mathrm{Ser}^{46}$ and $\mathrm{R}^{49}$ residues are highly conserved whereas mutation of the $(K / R)^{19}$ residue correlated with non-progression of HIV-I disease.
\end{abstract}

Conclusion: Our results indicate for the first time that Tat is phosphorylated in vivo; Tat phosphorylation is likely to be mediated by CDK2; and phosphorylation of Tat is important for HIV-I transcription. 


\section{Background}

The human immunodeficiency virus type 1 (HIV-1) requires host cell factors for all steps of the viral replication $[1,2]$. Recently, multiple covalent modifications of viral proteins that regulate virus-host protein interactions have been described, such as phosphorylation, acetylation and ubiquitination. Phosphorylation has been reported for almost all HIV-1 accessory proteins, including Vpu [3], Vpr [4], Vif [5], Nef [6], and Rev [7]. Transcription of HIV1 viral genes is induced by a viral transactivator protein (Tat) $[1,2]$. The activation domain of Tat (amino acids 148) interacts with host cell factors, whereas the positively charged RNA-binding domain (amino acids 49-57) interacts with HIV-1 transactivation response (TAR) RNA [1,2]. In cell-free transcription assays Tat induces exclusively elongation of transcription $[8,9]$. In vivo, Tat additionally induces initiation of transcription from the integrated HIV-1 promoter [10-12]. Tat stimulates formation of transcription complex containing TATA-box-binding protein (TBP) but not TBP-associated factors (TAFs), thus indicating that Tat may enhance initiation of transcription [10], apparently in agreement with the earlier observation that Tat binds directly to the TBP-containing basal transcription factor TFIID [13]. Tat activates HIV-1 transcription by recruiting transcriptional co-activators that include Positive Transcription Elongation Factor b (P-TEFb), containing CDK9/cyclin T1; an RNA polymerase II C-terminal domain kinase $[9,14,15]$ and histone acetyl transferases [16-18]. Whereas P-TEFb induces HIV-1 transcription from non-integrated HIV-1 template $[9,14,15]$, histone acetyl transferases allow induction of integrated HIV-1 provirus [16-18]. Additional CTD kinases, including CDK2 and CDK7 were also reported to be activated by Tat and to induce functional CTD phosphorylation $[19,20]$. Tat itself is a subject for covalent modifications by host cell proteins. Tat is directly acetylated at lysine 28 , within the activation domain, and lysine 50, in the TAR RNA binding domain [21]. Tat is also ubiquitinated at lysine 71 and its ubiquitination stimulates the transcriptional properties of Tat [22]. Recently, Tat was shown to be methylated by the arginine methyltransferase, PRMT6 and the arginine methylation of Tat negatively regulated its transcriptional activity [23]. Surprisingly, in spite of the interaction of Tat with P-TEFb and probably other kinases and its involvement in multiple protein phosphorylation reactions, the phosphorylation of HIV-1 Tat has only been reported in vitro [24], but not in vivo [25]. HIV-2 Tat was reported to be phosphorylated in vivo presumably by CDK9, but this phosphorylation was not important for Tat-2 function as a transcriptional activator [26]. We previously reported that Tat dynamically interacts with CDK2/cyclin E and is also phosphorylated by CDK2/cyclin $\mathrm{E}$ in vitro [20]. This dynamic interaction greatly stimulated the activity of CDK2/cyclin E toward phosphorylation of CTD in vitro [20]. In the present study we investigated whether Tat is phosphorylated in vivo and whether this phosphorylation has a regulatory role in Tatactivated HIV-1 transcription.

\section{Results}

Tat is phosphorylated by CDK2 in vitro and Ser- 16 and Ser-46 residues of Tat are potential phosphorylation sites We previously showed that Tat is phosphorylated by recombinant CDK2/cyclin E in vitro and that Tat's Ser16 was a potential phosphorylation site [20]. Indeed recombinant CDK2/cyclin E efficiently phosphorylates Tat (Fig. 1A, lane 1). Tat can also be phosphorylated by HeLa nuclear extract (Fig. 1A, lane 2). Immunodepletion of CDK2 from HeLa nuclear extract completely abolished Tat phosphorylation (Fig. 1A, lane 3) suggesting that under these conditions Tat was largely phosphorylated by CDK2. Upon analysis of the sequence of Tat, the (S/ $\mathrm{T})_{0} \mathrm{P}_{1} \mathrm{~K}_{2}(\mathrm{~K} / \mathrm{R})_{3}$ consensus motif for serine phosphorylation by CDK2 $[27,28]$ was not found, but several sequences were found that partially matched this motif: $\mathrm{S}^{16} \mathrm{QP}(\mathrm{K} / \mathrm{R})^{19}$, $\mathrm{S}^{46} \mathrm{YGR}^{49}{ }^{4} \mathrm{~S}^{68} \mathrm{LSK}^{71}$. To determine potential phosphorylation sites, Tat phosphorylated in vitro was analyzed by Mass spectrometry. For this purpose, purified recombinant Tat was phosphorylated with recombinant CDK2/cyclin E in vitro followed by immunoprecipitation, SDS-PAGE purification, in-gel digestion with trypsin, and HPLC purification. Analysis of HPLC eluates showed presence of two peaks in the digest generated from phosphorylated Tat that were absent in digest of nonphosphorylated Tat (Fig. 1B). These two peaks were collected and subjected to MALDI-TOF mass spectrometry. Masses of the peptides over 900 Da were acquired and analyzed with FindPep tool [29] using the sequence of Tat (MEPVDPNLEPWKHPGSQPRTACNNCYCKKCCFHCYA CFTRKGLGISYGRKKRRQRRRAPQDSQTHQASLSKQ) as input. The masses of peptides that did not match to Tat were further compared with Tat peptides from which we subtracted $18 \mathrm{Da}$, assuming $\beta$-elimination of phosphoric acid which is likely to occur during MALDI-TOF analysis [30]. Matched peptides shown in Table 1, indicate that Peak I contains peptides with Serine 46 as a potential phosphorylation site, whereas Peak II contains peptides with Serine 16 as a potential phosphorylation site. All matched peptides contain internal lysine or arginine residues, and thus they are apparently products of incomplete digestion by trypsin, which could be a result of incomplete in-gel digestion. Also acquisition of peptide with masses over 900 Da would only allow detection of relatively large peptides. The data suggest that Tat is phosphorylated in vitro by CDK2 and that this phosphorylation might take place at $\operatorname{Ser}^{16}$ or Ser ${ }^{46}$ residues within $\mathrm{S}^{16} \mathrm{QPR}{ }^{19}$ and $\mathrm{S}^{46} \mathrm{YGR}^{49}$ sequences that partially match to the (S/ $\mathrm{T}) \mathrm{P} \times(\mathrm{K} / \mathrm{R})$ consensus sequence for CDK2 phosphorylation [28]. 
Table I: Determination of sites of phosphorylation in Tat

\begin{tabular}{|c|c|c|c|c|}
\hline Peak & Peptides matching to Tat & MW & $-18 \mathrm{Da}$ & Matching peptides \\
\hline \multirow[t]{3}{*}{$\mathbf{I}$} & (T)RKGLGISYG(R) & 950.606 & 932.606 & $\begin{array}{l}932.606 \\
931.553\end{array}$ \\
\hline & (L)GISYGRKKRR/(Q) & 1220.7 & 1202.7 & $\begin{array}{c}\text { I } 202.7 \\
\mid 202.698\end{array}$ \\
\hline & (S)YGRKKRRQRR/(R) & 1403.779 & 1385.779 & $\begin{array}{l}\text { I } 385.779 \\
\text { I } 385.777\end{array}$ \\
\hline \multirow[t]{4}{*}{ II } & (L)EPWKHPGSQPRTACNNCYCK/(K) & 2319.272 & 2301.272 & $\begin{array}{l}2301.272 \\
2301.274\end{array}$ \\
\hline & (P)WKHPGSQPRTAC(N) & 1367.563 & 1349.563 & $\begin{array}{l}\text { I349.563 } \\
\text { I349.544 } \\
\text { I } 349.563 \\
\text { I } 349.544\end{array}$ \\
\hline & (P)WKHPGSQPRTACNN(C) & $|595.8| \mid$ & $|577.81|$ & $\begin{array}{l}\text { I577.8II, } \\
\text { |576.779 }\end{array}$ \\
\hline & (P)NLEPWKHPG(S) & 1077.606 & 1059.606 & 1059.606 \\
\hline
\end{tabular}

\section{Tat is phosphorylated in cultured cells}

Previous attempts to detect Tat phosphorylation in vivo were unsuccessful [25]. We hypothesized that low level of Tat expression after transfection and/or rapid de-phosphorylation by cellular phosphatases might prevent detection of Tat phosphorylation in vivo. To overcome these difficulties, we expressed Flag-tagged Tat which we found to be expressed to a higher level in COS-7 cells than untagged Tat (Fig. 2, compare lanes 3 and 4). To facilitate expression of Flag-Tat in HeLa cells we used adenovirusmediated expression of Tat [31]. HeLa cells were infected with Adeno-Tat and incubated 48 hours post infection to allow expression of Tat. Then cells were pulsed with (32P)labeled orthophosphate, and Tat was immunoprecipitated from cellular lysates using monoclonal anti-Flag or polyclonal anti-Tat antibodies. Immunoprecipitated proteins were resolved by SDS-PAGE on 15\% Tris-Tricine gel [32] and transferred to PVDF membrane. The membrane was probed with monoclonal anti-Tat antibodies (Fig. 3A) using 3,3'-Diaminobenzidine enhancer system (DABM, Sigma), and also exposed to a PhosphoImager screen (Fig. $3 \mathrm{~B})$. Both antibodies precipitated a well detectable amount of Tat protein (Fig. 3A, lanes 3, 4, 6 and 7). Under these experimental conditions, Tat was phosphorylated (Figs. 3B and 3C, compare lane 3 to lane 1 and lane 6 to lane 5). Next we treated cells with okadaic acid, an inhibitor of PPP-type phosphatases, to prevent rapid dephosphorylation of Tat in the cells and during the lysis procedure. Treatment with okadaic acid did not change the amount of precipitated Tat (Fig. 3A, lanes 3, 4, 6 and 7). In contrast, Tat phosphorylation was significantly enhanced when cells were treated with okadaic acid (Figs.3B and 3C, lanes 4 and 7). Taken together, these results indicate that Tat is phosphorylated in vivo and that Tat phosphorylation is enhanced when cells are treated with the inhibitor of PPP-phosphatases.

\section{CDK2 phosphorylates Tat in cultured cells}

We next investigated whether Tat phosphorylation was mediated by CDK2 in vivo using CDK2-directed RNA interference [33]. HeLa cells were infected with Adeno-Tat and subsequently transfected with siRNAs against CDK2. Transfection of HeLa cells with siRNAs against CDK2 decreased the level of expression of CDK2 by 2.5 -fold (Figs. 4A and 4B, lane 3). A control non-targeting siRNA pool did not affect expression of CDK2 (Figs. 4A and 4B, lane 2). The non-targeting siRNA control was used to ensure that transfection itself did not affect CDK2 expression. Western blot analysis of tubulin and CDK9 was used as control for the specificity of siRNAs. As shown in Fig. 4A transfection with both siRNAs did not affect the level of $\alpha$-tubulin expression. To ensure that CDK2-directed siRNA decreased the enzymatic activity of cellular CDK2, CDK2 was immunoprecipitated from cells transfected with non-targeting or CDK2-directed siRNA and assayed for its enzymatic activity using recombinant Tat as a substrate. The activity of CDK2 was decreased in the cells transfected with CDK2-directed siRNA (Fig. 4C, lane 2) as compared to the cells transfected with non-targeting siRNA (Fig. 4C, lane 1). Next the cells were infected with Adeno-Tat, transfected with non-targeting or CDK2directed siRNAs and pulse-labeled with $\left({ }^{32} \mathrm{P}\right)$. In this experiment no okadaic acid was used. Inhibition of CDK2 by siRNA reduced the level of Tat phosphorylation by 3 fold (Figs. 5A,B and 5C, compare lanes 2 and 3). Thus CDK2 is likely to mediate Tat phosphorylation in cultured cells. To analyze whether Tat and CDK2 might be present in the same molecular weight complex, we analyzed sedimentation of Tat and CDK2 by ultracentrifugation on a glycerol gradient (Fig. 6). Both Tat and CDK2 co-migrated in fractions 1-8 (Fig. 6). The CDK9 was present in most of the fractions with the peak in fractions 4-5 and 9-10 (Fig. 6 ), which is likely to correspond to low and high molecu- 
A
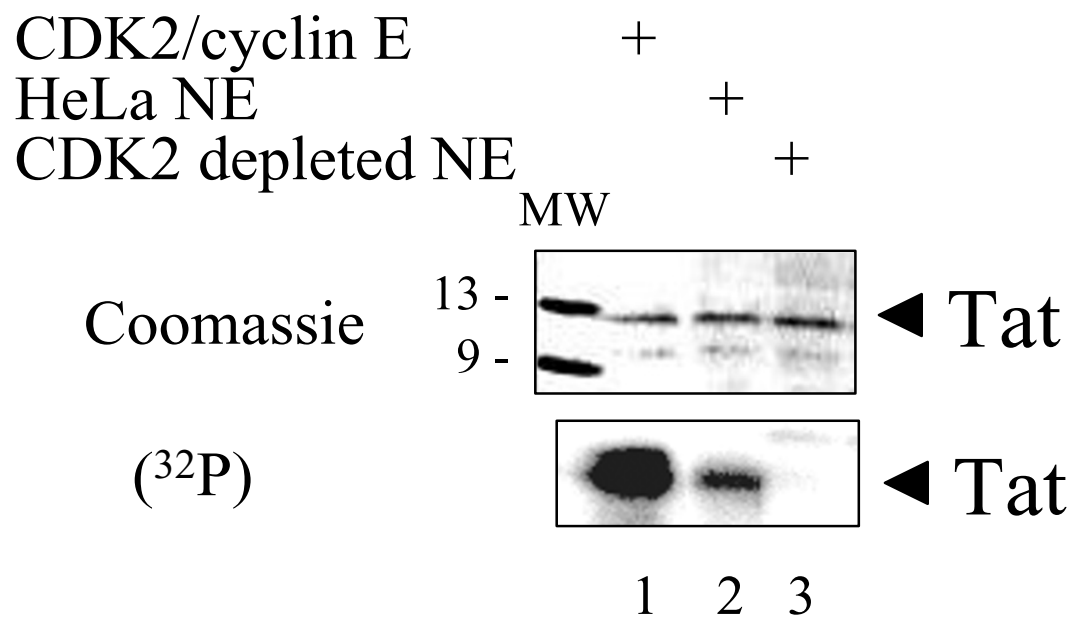

B

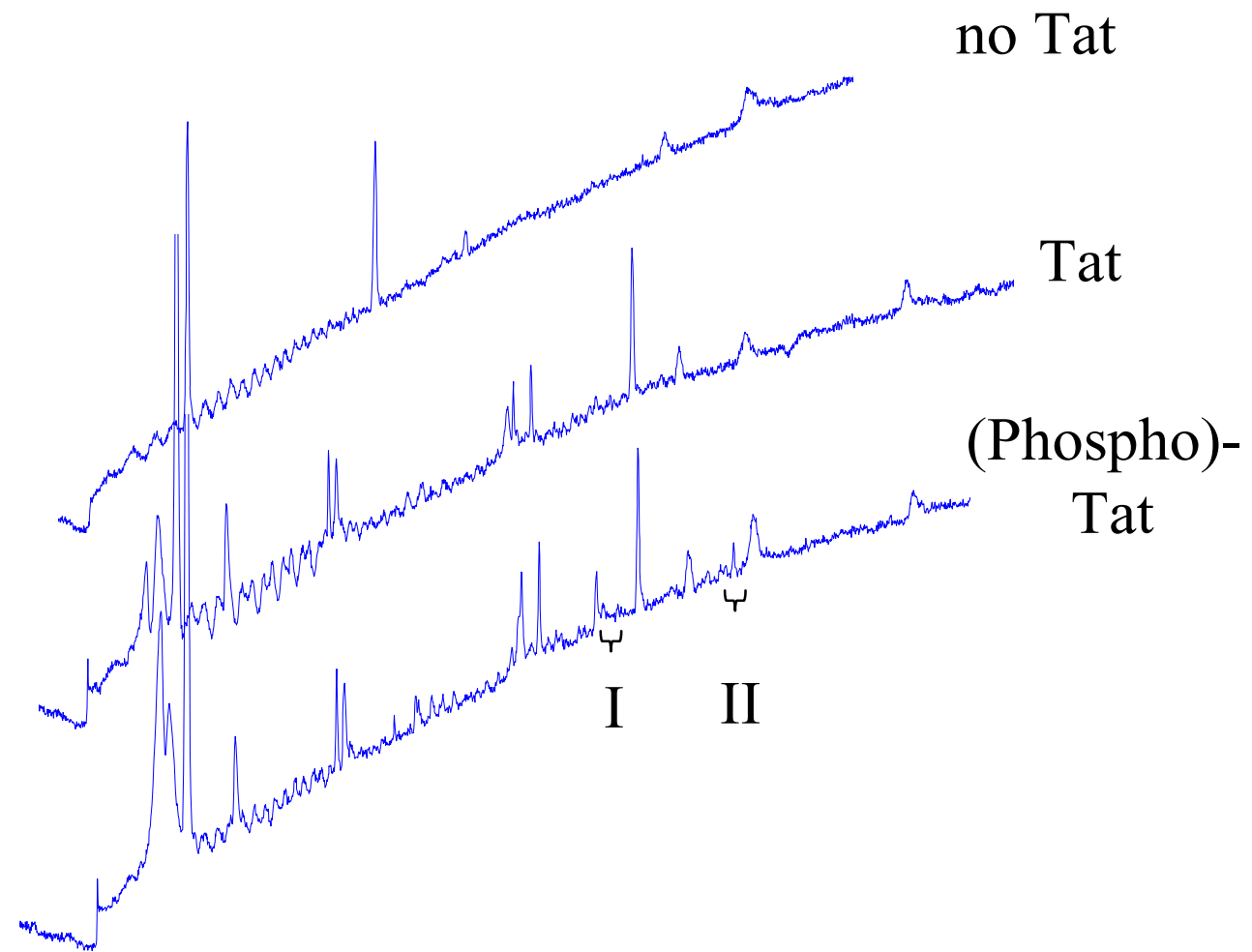

Figure I

Analysis of HIV-I Tat phosphorylated by CDK2/cyclin E in vitro. A, Tat is phosphorylated by CDK2. Recombinant Tat was phosphorylated in vitro by purified CDK2/cyclin E (lane I), by HeLa nuclear extract (lane 2) or by CDK2-depleted HeLa nuclear extract (lane 3). Tat was resolved by I2\% SDS Tris-Tricin PAGE. The gel was stained with Coomassie blue (upper panel) and exposed to Phospho Imager screen (lower panel). B, HPLC profiles of Tat peptides after trypsin cleavage. Recombinant Tat was phosphorylated in vitro by purified CDK2/cyclin E, resolved by I2\% SDS Tris-Tricin PAGE, and subjected to in-gel trypsin digestion. The eluted peptides were resolved by reverse phase chromatography on $\mu \mathrm{RPC} \mathrm{C} 2 / \mathrm{Cl} 8$ ST 4.6/I00 column. No Tat, mock trypsin digest without Tat. Tat, digest of non-phosphorylated Tat. (Phospho)-Tat, digestion of phosphorylated Tat. I and II, peaks identified in the elution profile of phosphorylated Tat that were subjected to MALDI TOF/ TOF mass spectrometry. 


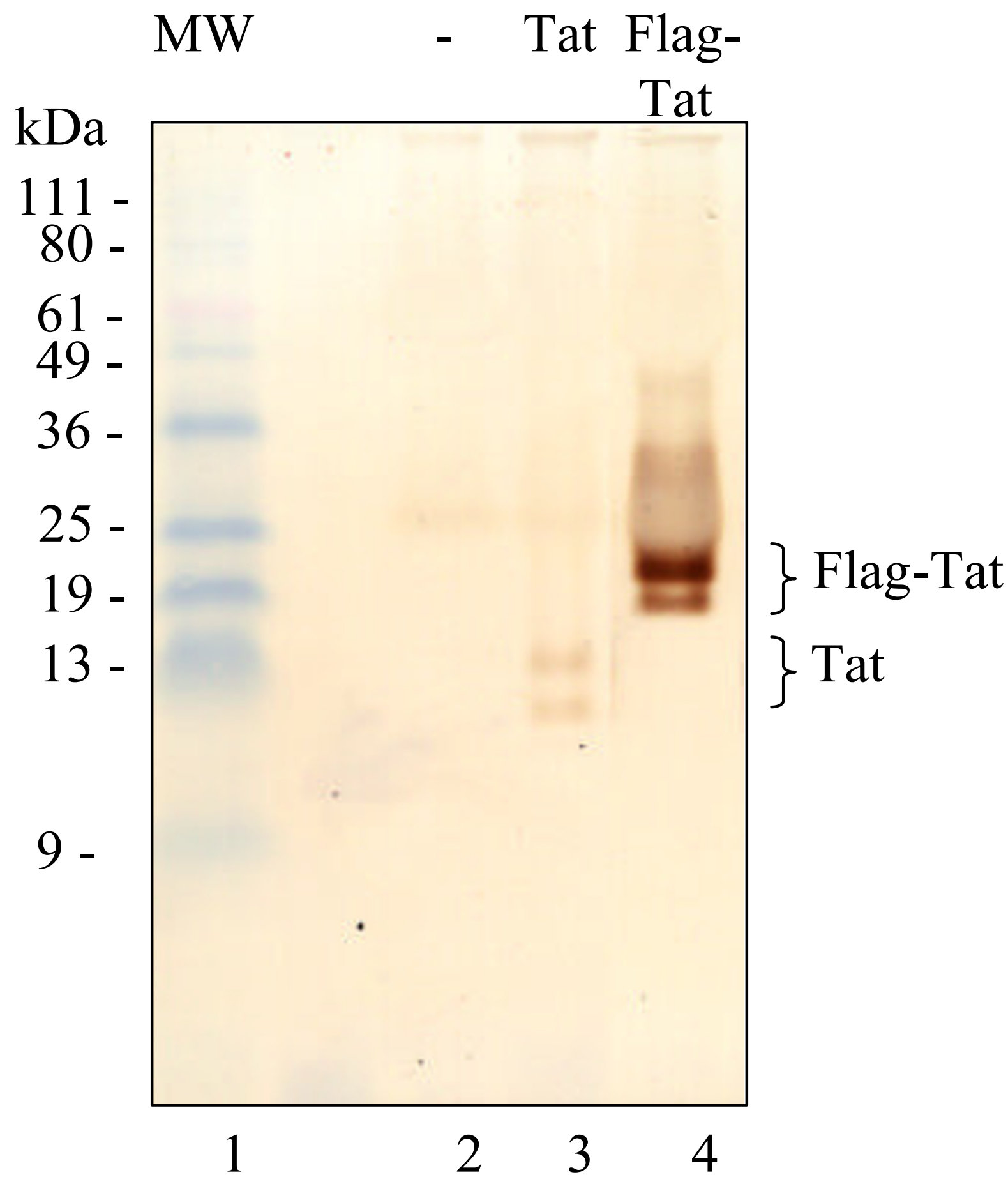

Figure 2

Expression of untagged and Flag-tagged Tat. COS-7 cells were transfected with Tat (lane 3) and Flag-tagged Tat (lane 4) expression vectors or mock-transfected (lane 2). At 48 hours post transfection cells were lysed and Tat was immediately immunoprecipitated with anti-Tat rabbit polyclonal antibodies (lanes 2-4). Immunoprecipitated Tat was resolved by I5\% TrisTricine SDS-PAGE, transferred to polyvinylidene fluoride membrane and immunoblotted with anti-Tat monoclonal antibodies using the 3,3'-diaminobenzidine enhancer system. Positions of Tat and Flag-Tat are indicated. Lane I, prestained I0 kDa molecular weight markers. 
A
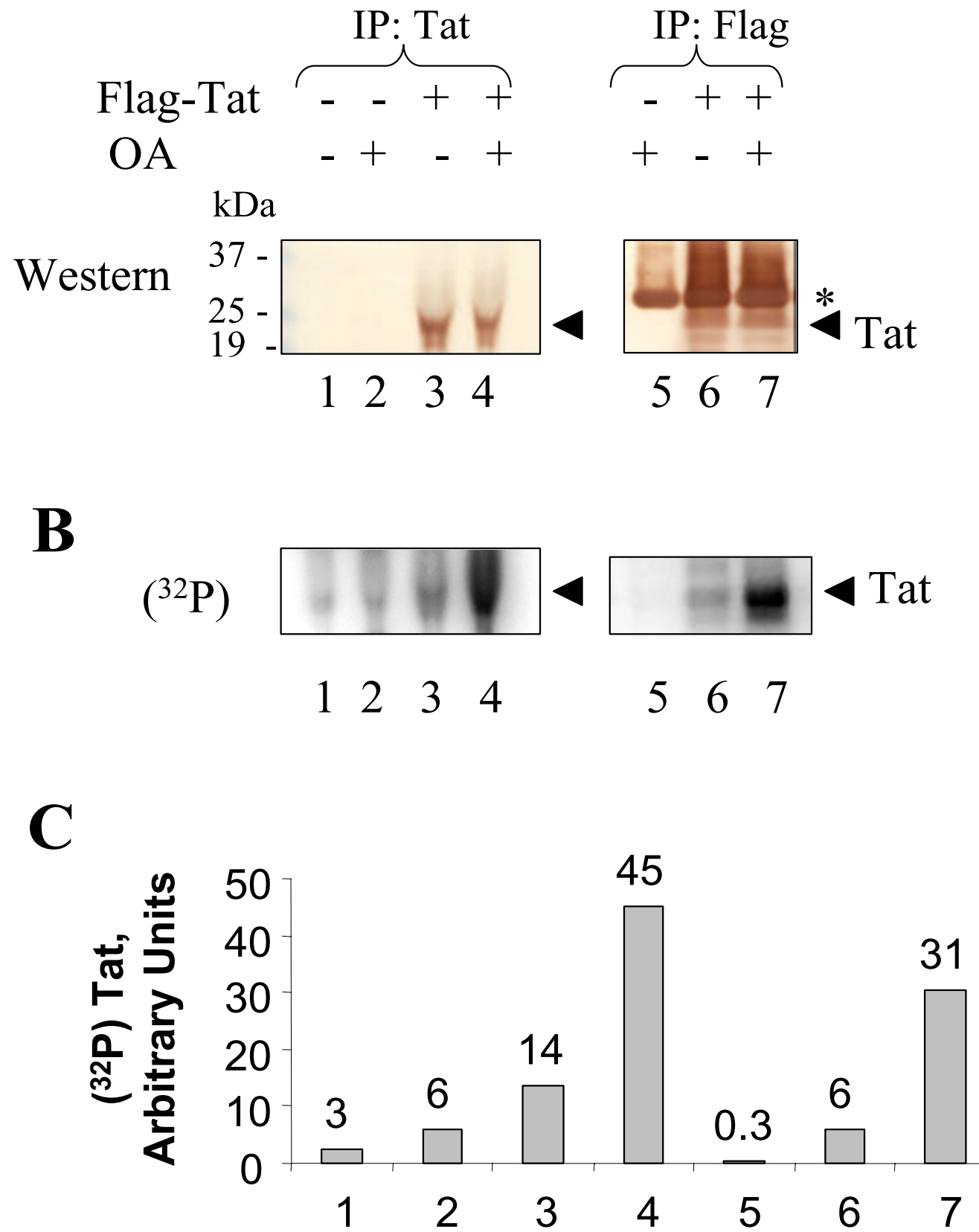

Figure 3

HIV-I Tat is phosphorylated in cultured cells. HeLa cells were infected with recombinant adenovirus expressing Flagtagged Tat as described in Methods (lanes 3, 4, 6 and 7). Lanes I, 2, and 5 - control uninfected cells. At 48 hours post infection cells were labeled with ( $\left.{ }^{32} \mathrm{P}\right)$-orthophosphate for 2 hours without (lanes I, 3 and 6) or with (lanes 2, 4, 5 and 7) I $\mu$ M okadaic acid (OA). Whole cell extracts were prepared and Tat was immunoprecipitated with anti-Tat rabbit polyclonal antibodies (lanes I-4) or anti-Flag monoclonal murine antibodies (lanes 5-7). Immunoprecipitated Tat was resolved by I5\% Tris-Tricine SDS-PAGE, and transferred to polyvinylidene fluoride membrane. $A$, immunoblot of the membrane with anti-Tat monoclonal antibodies using the 3,3'-diaminobenzidine enhancer system. B, autoradiography of the membrane on Phosphor Imager. C, quantification of panel B. The position of light chain of IgG recognized in anti-Flag immunoprecipitates by anti-mouse HRP-conjugated secondary antibodies is indicated by asterisk. 
lar weight P-TEFb complexes. HEXIM1, and Brd4 were mostly present in fractions 2-6, although HEXIM1 was also detected in higher molecular weight fractions 10 and 11 (Fig. 6). Neither Tat nor CDK2 co-migrated with RNAPII which was present in fractions 1-13 (Fig. 6). We further analyzed association of Tat with CDK2 by immunoprecipitation. Flag-Tat was expressed in HeLa cells by infection with Adeno-Tat and precipitated from cellular extracts with anti-Flag antibodies (Fig. 7A). CDK2 co-precipitated with Tat (Fig. 7A, lane 4). CDK2 was not precipitated with anti-Tat antiserum from non-infected cells (Fig. 7A, lane 3) or not with non-specific preimmune serum from adeno-Tat infected cells (Fig. 7A, lane 5). Inhibition of CDK2 expression by CDK2-specific RNAi significantly reduced CDK2 co-precipitated to Tat apparently due reduction of the expressed CDK2 (Fig. 7B, compare lane 4 to lane 2). Association of Tat with CDK9 was slightly reduced (Fig. 6B) but this reduction correlated to the decreased amount of Tat precipitated by anti-Flag antibodies. Binding of Tat-cyclin T1 was not reduced (Fig. 7C, lanes 3 and 5). The cyclin T2 did not precipitate with Tat (Fig. 7C), which indicated a specificity of the immunoprecipitation. Taking together, these results suggest that CDK2 associates with Tat in cultured cells, and that inhibition of CDK2 expression prevents Tat phosphorylation. Thus, CDK2 is likely to phosphorylate Tat directly in cultured cells.

\section{Tat is phosphorylated on serine residues in vivo}

We next determined whether serine, threonine or tyrosine residues of Tat were phosphorylated in vivo. HeLa cells were infected with Adeno-Tat, labeled with (32P), and treated with okadaic acid to achieve a higher level of Tat phosphorylation. Tat was immunoprecipitated with antiFlag antibody and resolved on 15\% SDS Tris-Tricine PAGE (Fig. 8A, lane 1). Phosphoamino acid analysis of radioactive Tat extracted from the gel (see Materials and Methods) showed presence of phospho-serines but not phosphothreonines or phospho-tyrosines in (32P)-labeled Tat (Fig. $8 \mathrm{~B})$. Thus, only serine residues of Tat were phosphorylated in vivo.

\section{Phosphorylation of $S^{16}$ and $S^{46}$ residues of Tat in vivo}

We next investigated a possibility that Tat might be phosphorylated on $\mathrm{S}^{16}$ or $\mathrm{S}^{46}$ residues in vivo. We generated mutants of Flag-Tat in which either or both Ser residues were substituted by Ala. $293 \mathrm{~T}$ cells were transfected with WT and mutant Tat-expressing vectors, Tat was precipitated with anti-Flag antibodies and analyzed on 15\% SDS Tris-Tricine PAGE followed by PhosphoImager analysis. Expression of Tat was verified by Western blotting (Fig. $8 \mathrm{C}$ ). While we could detect phosphorylation of WT Tat (Fig. 8C, lane 2), the Tat S16A mutant and Tat S46A mutant were about 2-3 fold less phosphorylated (Fig. 8C, middle and lower panels, lanes 3 and 4). The Tat S16,46A double mutant was even less phosphorylated (Fig. 8C, lane 5). Our results indicate that both $S^{16}$ and $S^{46}$ are likely to be phosphorylated in vivo.

\section{Contribution of $S^{16}$ and $S^{46}$ residues of Tat to HIV-I transcription}

We next investigated the functional relevance of Tat's $S^{16}$ and $\mathrm{S}^{46}$ residues in HIV-1 transcription. We generated mutants of Tat in which either or both Ser residues were substituted by Ala. To ensure expression of the mutants, COS-7 cells were transfected with WT and mutant Tatexpressing vectors and cellular lysates were analyzed on 15\% SDS Tris-Tricine PAGE followed by Western blot with anti-Tat antibodies. As shown in Fig. 9A, all Tat mutants were expressed, with the level of expression of Tat mutants higher than the WT Tat. The higher expression level of non-tagged Tat mutants was a reproducible effect and was not a consequence of the difference in the amount of transfected DNA. The effect of Tat mutations on the ability of Tat to activate HIV-1 LTR promoter was analyzed in HeLa cells co-transfected with Tat-expression vectors and HIV-1 LTR-LacZ reporter plasmid (Fig. 9B). Non-mutated Tat (WT) increased the level of transcription by 400-fold (Fig 9B). HIV-1 transcription induction by the Tat S16A mutant was approximately $75 \%$ that of WT Tat (Fig. 9B), while transactivation by the Tat S46A mutant was about 2 times lower than with the WT Tat (Fig. 9B) and induction by the double S16, 46A Tat mutant was 3times lower than that of WT Tat (Fig. 9B). Thus, mutation of either $\operatorname{Ser}^{16}$ or $\operatorname{Ser}^{46}$ of Tat interferes with the level of Tat-transactivation and mutation of both residues has an additive effect.

\section{Contribution of $S^{16}$ and $S^{46}$ residues of Tat to the HIV-I viral production and Tat phosphorylation in the context of the integrated HIV-I provirus}

We determined whether mutations of Tat S16A and/or S46A have an effect on the ability of Tat to induce HIV-1 transcription from an integrated HIV-1 provirus. We used HLM-1 cells (AIDS Research and Reference Reagent Program) that were derived from HeLa-CD4+ cells containing an integrated copy of HIV-1 proviral genome with a Tatdefective mutation (termination linker at the first AUG). HLM-1 cells are negative for virus particle production, but can be induced to express high levels of infectious HIV-1 after transfection with Tat. We transfected the HLM-1 cells with wild type or mutant Tat vectors and tested supernatants for the presence of HIV-1 particles using p24 gag antigen ELISA at day 0 , day 1 , day 2, day 7 and day 14 posttransfection. Neither S16A nor S46A mutants of Tat efficiently induced HIV-1 viral production (Fig. 10A). The double S16, 46A mutant also had a reduced activity (Fig. 10A). To phosphorylate Tat during virus replication, we pulsed HLM-1 cells transfected with WT and mutant Tat with ( $\left.{ }^{32} \mathrm{P}\right)$ orthophosphate and also treated the cells with 
A

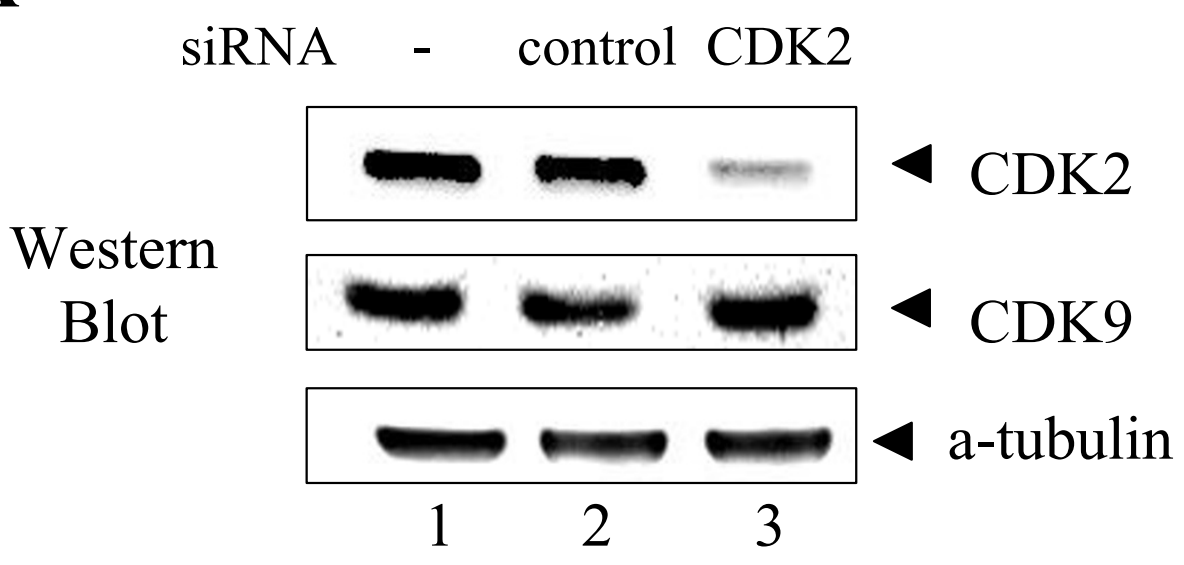

B
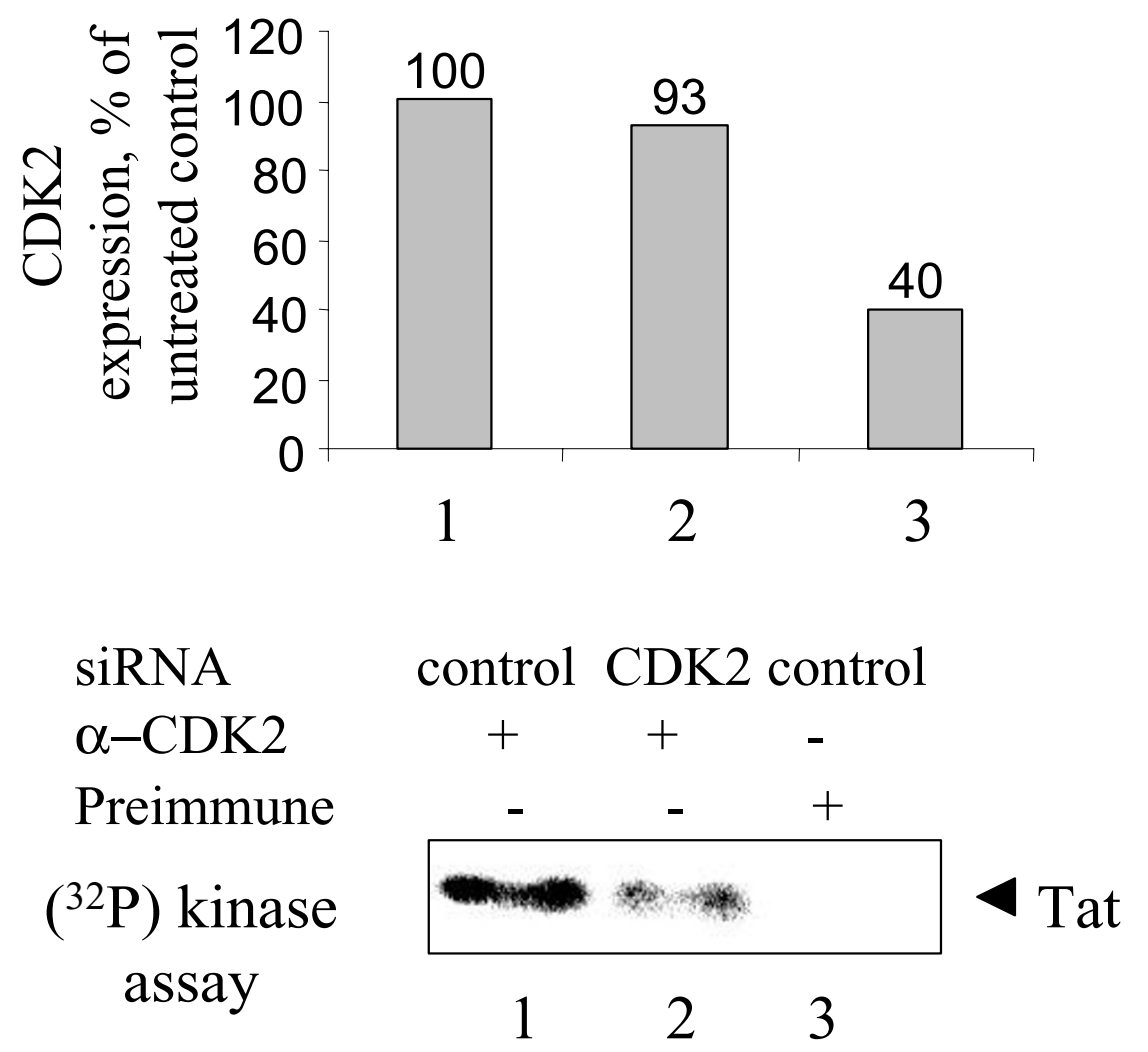

Figure 4

CDK2-directed siRNA inhibits CDK2 expression. A, CDK2-directed siRNA inhibits expression of CDK2. HeLa cells were transfected with siRNAs targeting CDK2 (lane 3) or non-targeting control pool (control, lane 2). Lane I, untransfected cells. At 48 hours post-transfection cells were lysed and cellular extracts were resolved on I2\% Tris-Tricine SDS-PAGE and analyzed by immunoblotting analysis with antibodies against CDK2, CDK9 or $\alpha$-tubulin. $B$, quantification of the CDK2 expression in panel $A$ using $\alpha$-tubulin expression level for normalization. C, CDK2-directed siRNA inhibits enzymatic activity of CDK2. CDK2 was precipitated from cellular extracts prepared from HeLa cells transfected with siRNAs targeting CDK2 (lane 2) or non-targeting control (lanes I and 3). Lanes I and 2, precipitation with rabbit anti-CDK2 antibodies. Lane 3, precipitation with rabbit preimmune serum. Immunoprecipitates were incubated with $\gamma$-(32P)ATP and recombinant Tat (see Methods), resolved on I2\% Tris-Tricine SDS-PAGE and analyzed by autoradiography on Phosphor Imager. Position of Tat is indicated. 


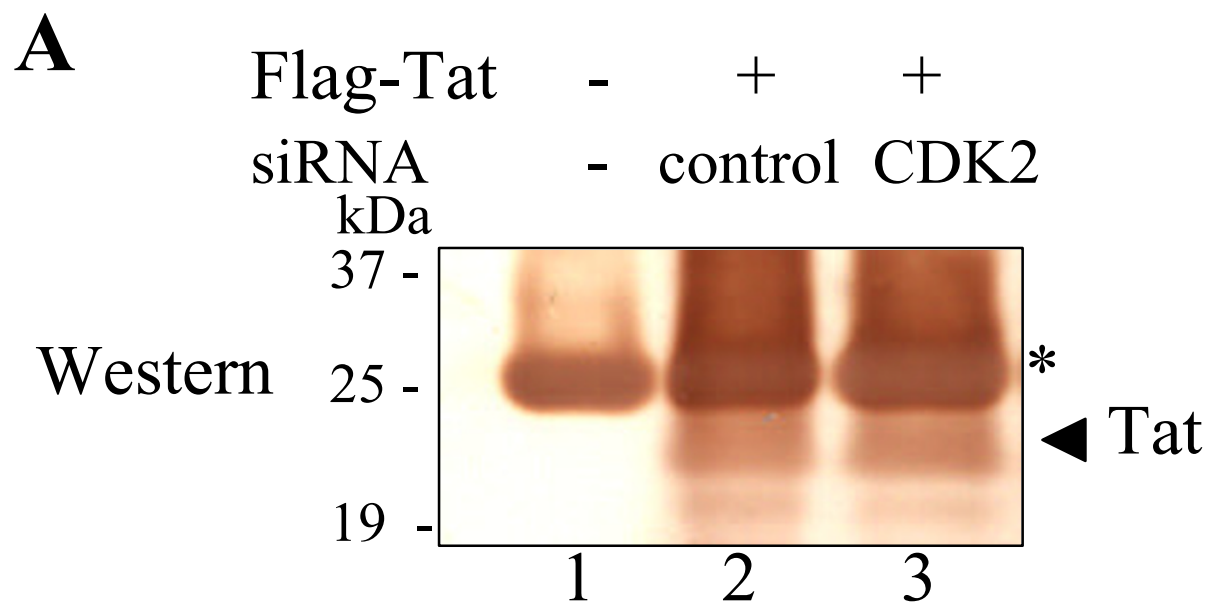

B
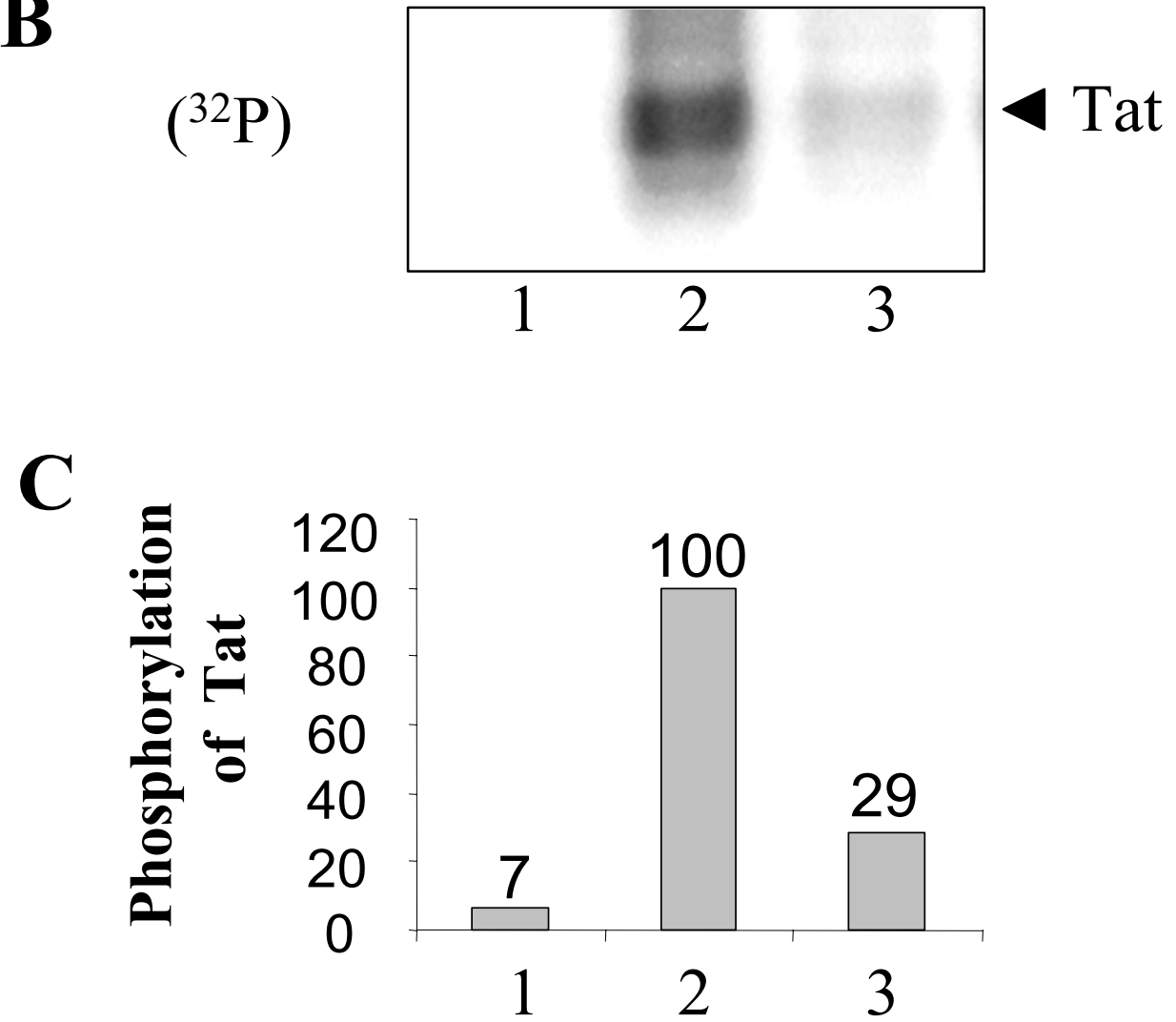

Figure 5

CDK2-directed siRNA blocks Tat phosphorylation. A, HeLa cells were infected with Adeno-Tat (lanes 2 and 3). At 4 hours post infection, cells were transfected with siRNAs targeting CDK2 (lane 3) or non-targeting control pool (lane 2). Lane I - control cells. At 48 hours post-infection cells were labeled with ( $\left.{ }^{32} \mathrm{P}\right)$-orthophosphate for 2 hours. Whole cell extract was subjected to immunoprecipitation with anti-Flag antibodies, resolved by I5\% Tris-Tricine SDS-PAGE, and transferred to polyvinylidene fluoride membrane. A, immunoblot of the membrane with anti-Tat monoclonal antibodies using the 3,3'-diaminobenzidine enhancer system. $B$, autoradiography of the membrane on Phosphor Imager screen. $C$, quantification of the panel $B$.

Position of Tat is indicated by arrow. The position of light chain of IgG recognized in anti-Flag immunoprecipitates by antimouse HRP-conjugated secondary antibodies is indicated by asterisk. 


\section{0\%-30\% Glycerol gradient

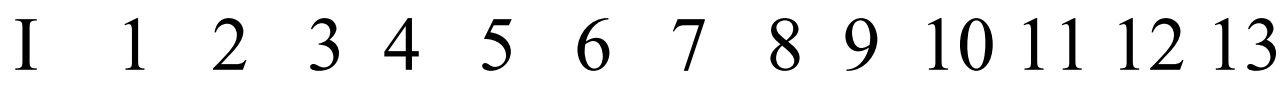

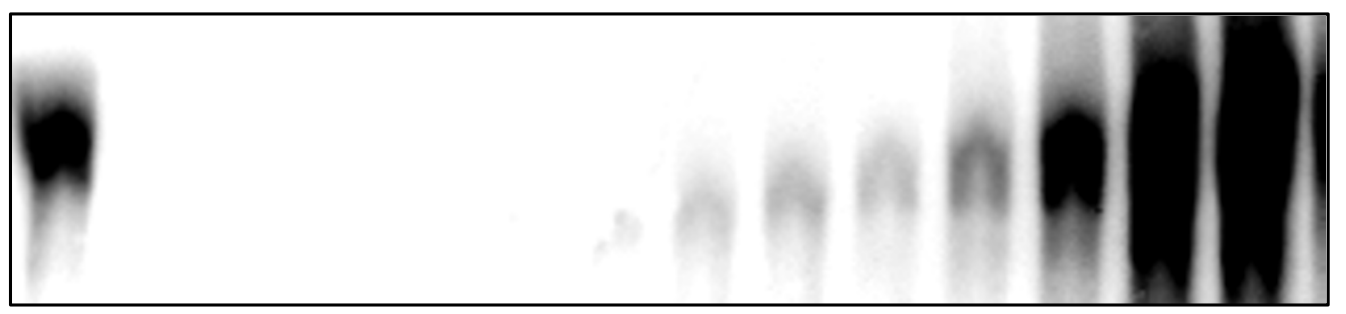

RNAPII

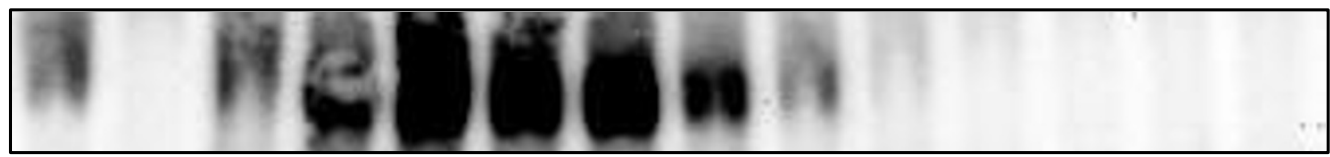

$\operatorname{Brd} 4$

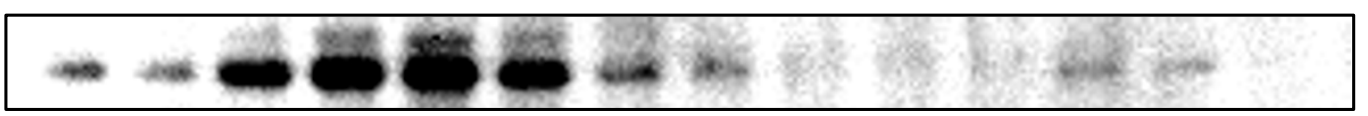

\section{HEXIM1}

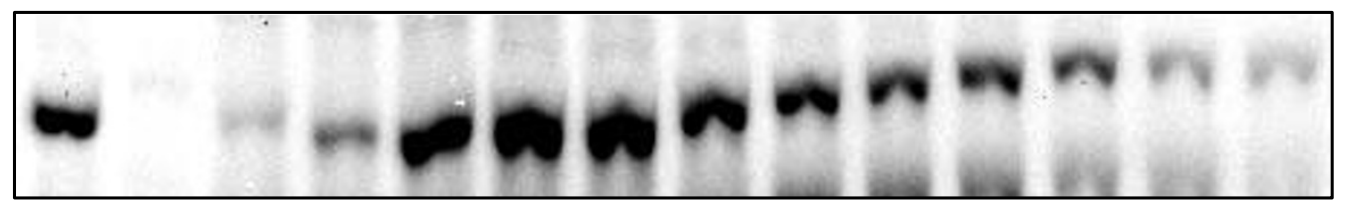

Cyclin T1

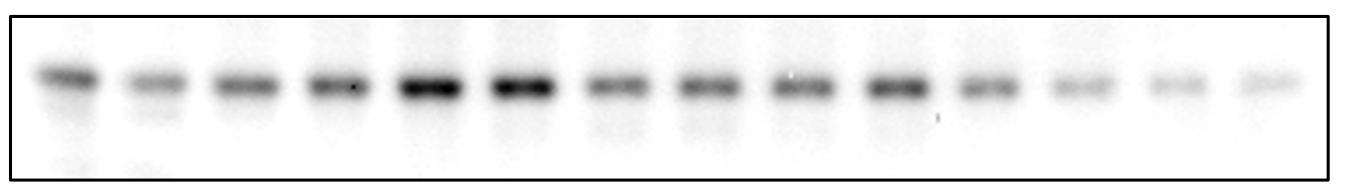

\section{CDK9}

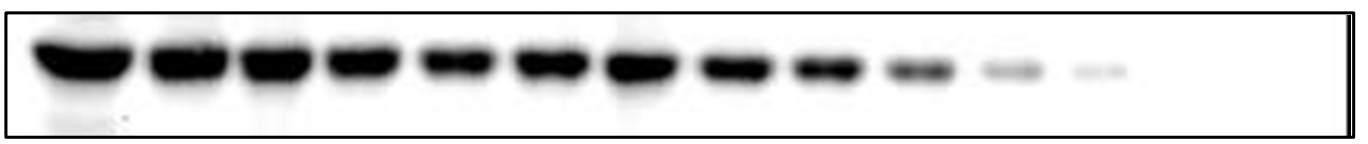

\section{CDK2}

\section{Flag-Tat}

Figure 6

Tat and CDK2 co-migrate on glycerol gradient. 293T cell lysated from the cells infected with Adeno-Tat were fractionated on 10\%-30\% glycerol gradients by centrifugation and analyzed with indicated antibodies by Immunoblotting.

okadaic acid. Tat was immunoprecipitated with anti-Flag antibodies, resolved on 15\% SDS PAGE and its phosphorylation was detected by PhosphoImager. While WT Tat was phosphorylated, the mutants were not phosphorylated efficiently (Fig. 10B). These data indicate that the S16A and S46A mutations of Tat interfere with the ability of Tat to activate integrated HIV-1 provirus, and prevent Tat phosphorylation during one round of viral replication.

\section{Correlation of mutations in putative CDK2 recognition} sites on Tat with disease progression in HIV infected humans

As we discussed above, analysis of the sequence of Tat for the presence of the $(\mathrm{S} / \mathrm{T})_{0} \mathrm{P}_{1} \mathrm{~K}_{2}(\mathrm{~K} / \mathrm{R})_{3}$ consensus motif for serine phosphorylation by CDK2 $[27,28]$ showed that several sequences partially matched this motif: ${ }^{16} \mathrm{SQP}(\mathrm{K} /$ R) ${ }^{19}, 46$ SYGR $^{49},{ }^{68}$ SLSK $^{71}$. We determined conservancy of $\mathrm{S}^{16}, \mathrm{~S}^{46}$ and $\mathrm{S}^{68}$ residues. We analyzed 158 sequences of 


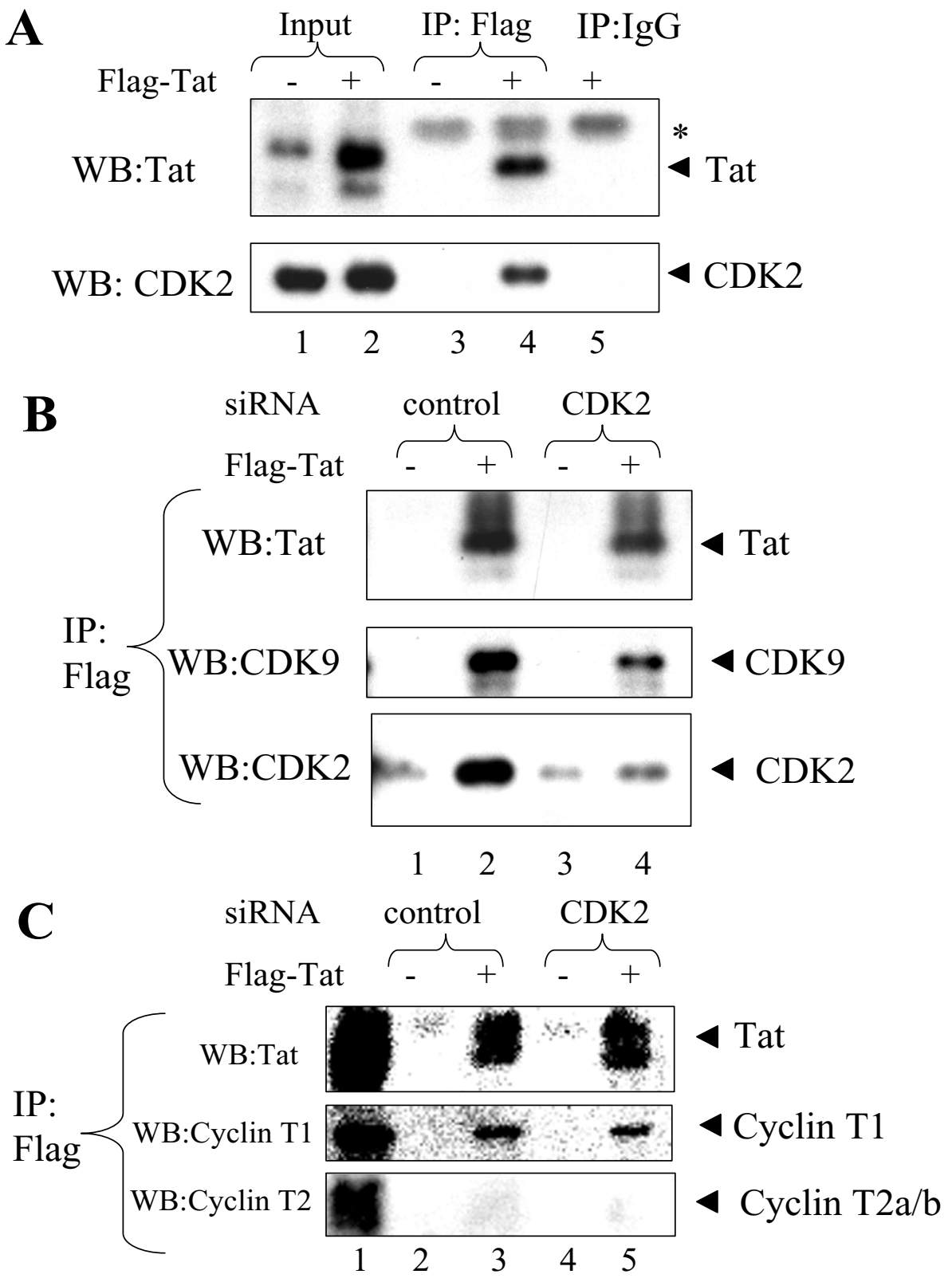

\section{Figure 7}

A, CDK2 associates with Tat in cultured cells. Flag-tagged Tat was expressed in HeLa cells by Adeno-Tat infection and precipitated with anti-Flag antibodies from cellular lysate. Co-precipitated proteins were resolved on I2\% Tris-Tricine PAGE and analyzed by immunoblotting analysis with anti-CDK2 and anti-Tat antibodies. Lane I, input control without Tat. Lane 2, input control with Tat. Lanes 3 and 4, extract without or with Tat precipitated with anti-Flag antibodies. Lane 5, extract with Tat precipitated with preimmune mouse $\lg$. The position of light chain of $\lg$ G recognized in anti-Flag immunoprecipitates by anti-mouse HRP-conjugated secondary antibodies is indicated by asterisk. B, CDK2-specific siRNA inhibits association of Tat with CDK2. Flag-tagged Tat was expressed in 293T cells by transfection (lanes 2 and 4). Cells were transfected with nontargeting (lanes I and 2) or CDK2-specific (lanes 3 and 4) siRNAs. Lysates were precipitated with anti-Flag antibodies, resolved on $12 \%$ Tris-Tricine PAGE and immunoblotted with anti-Tat, anti-CDK9 or anti-CDK2 antibodies. C, CDK2-specific siRNA does not affect association of Tat with cyclin TI. Flag-tagged Tat was expressed in 293T cells by transfection (lanes 3 and 5). Cells were transfected with non-targeting (lanes 2 and 3) or CDK2-specific (lanes 4 and 5) siRNAs. Lysates were precipitated with anti-Flag antibodies, resolved on $12 \%$ Tris-Tricine PAGE and immunoblotted with anti-Tat, anti-CDK9 or antiCDK2 antibodies. Lane I, input. 

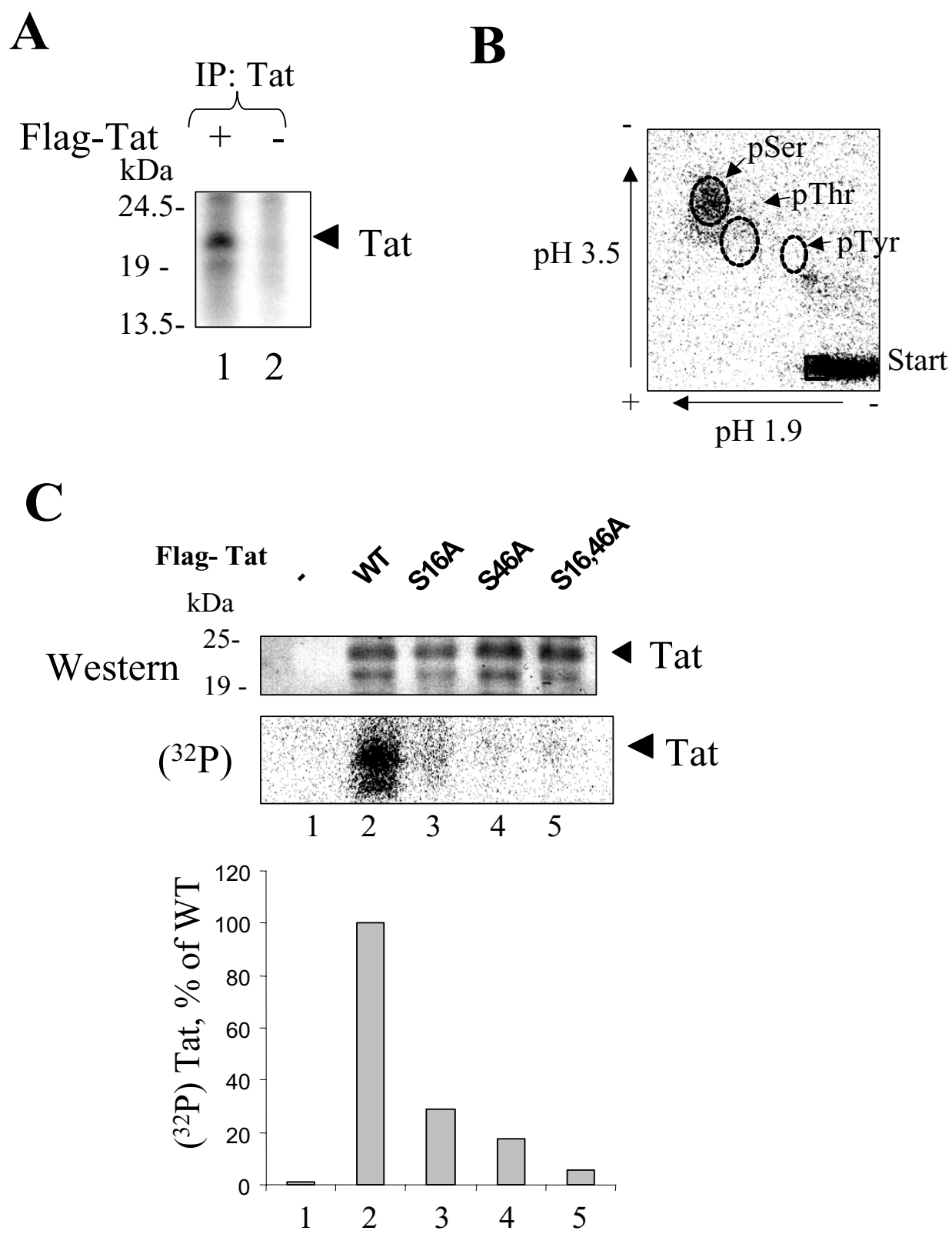

\section{Figure 8}

HIV-I Tat is phosphorylated on $\mathbf{S}^{16}$ and $\mathbf{S}^{46}$ residues in vivo. A, HeLa cells were infected with recombinant adenovirus expressing Flag-tagged Tat as described in Methods. At 48 hours post infection cells were labeled with ( $\left.{ }^{32} \mathrm{P}\right)$-orthophosphate for 2 hours with I $\mu$ M okadaic acid (OA). Lane I, Flag-Tat was immunoprecipitated from whole cell extracts with anti-Flag antibodies and resolved by I5\% Tris-Tricine SDS-PAGE. Lane 2, control mock-transfected cells. The picture is an autoradiogram. $\boldsymbol{B}$, Tat peptides were eluted from the gel shown in panel $A$ by overnight incubation with trypsin and subjected to acid hydrolysis as described in Materials and Methods. The hydrolyzed material was spotted on nitrocellulose plate and examined by twodimensional thin layer electrophoresis and autoradiography. The indicated positions of non-radioactive phospho-amino acid standards were visualized by staining with $0.5 \%$ ninhydrin in ethanol. C, Mutations of S 16 and S46 reduce Tat phosphorylation in vivo. 293T cells were transfected with vectors expressing Flag-tagged WT Tat (lane 2), Tat SI6A (lane 3), Tat S46A (lane 4) or Tat SI6,46A (lane 5). Lane I, mock transfection. At 48 hours post-transfection the cells were labeled with (32P)-orthophosphate for 2 hours. Whole cell extract was subjected for immunoprecipitation with anti-Flag antibodies, resolved by I5\% TrisTricine SDS-PAGE, and analyzed by Western blotting with polyclonal anti-Tat antibodies and on Phosphor Imager. Quantification is shown in the lower panel. Position of Tat is indicated by arrow. 


\section{A pTat - WT S16A S46A S16,46A}

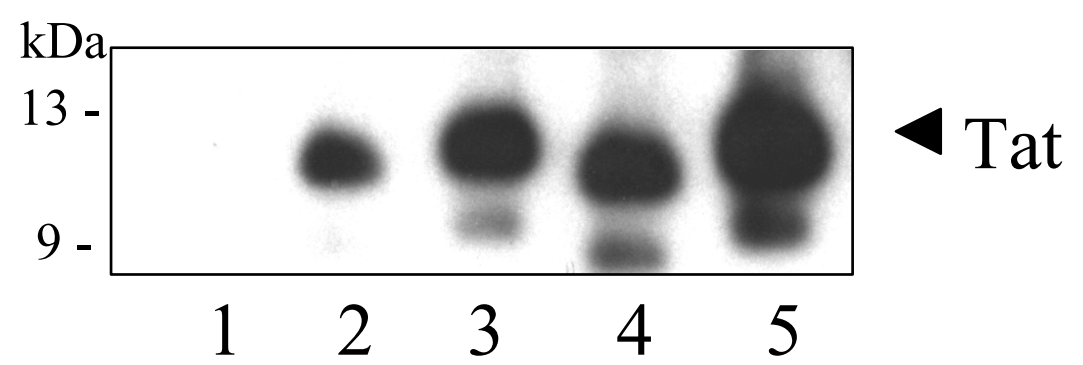

B

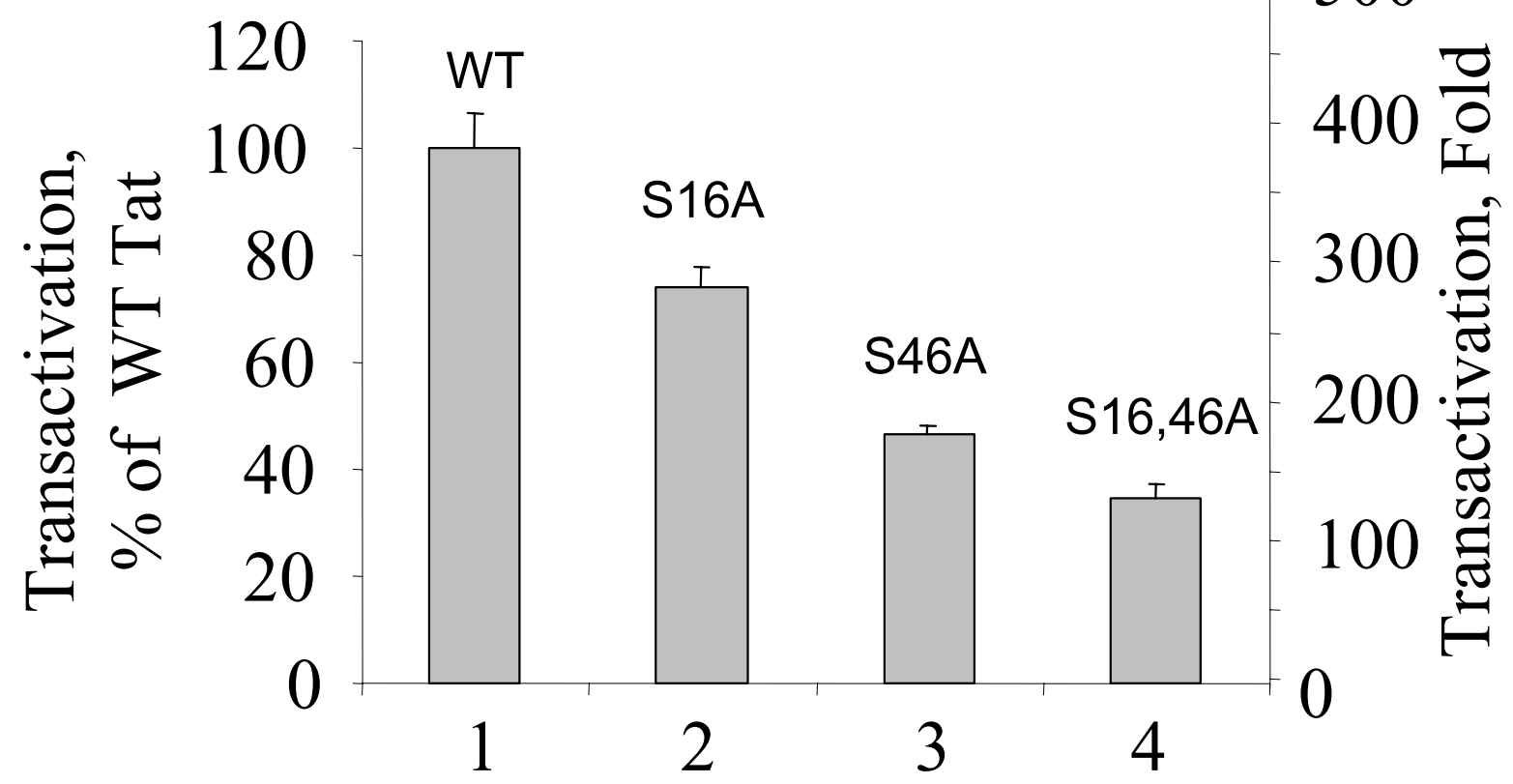

Figure 9

Mutations of Ser ${ }^{16}$ and Ser ${ }^{46}$ of Tat reduce its transactivation potential. A, COS-7 cells were transfected with WT Tat, Tat SI6A, Tat S46A or Tat S16,46A expression vectors. At 48 hours posttransfection, the cells were lysed. Tat was immunoprecipitated from the lysates with rabbit polyclonal antibodies, resolved by I5\% Tris-Tricine SDS-PAGE and immunoblotted with monoclonal anti-Tat antibodies. B, HeLa cells were transfected with the HIV-I LTR-LacZ expression vector alone (not shown here) and in combination with WT Tat, Tat SI6A, Tat S46A or Tat S16,46A expression vectors. At 48 hours posttransfection, cells were lysed and analyzed for $\beta$-galactosidase activity with ONPG.

Tat isolates deposited in the PubMed database. Both S16 and $S^{46}$ were highly conserved with an occurrence of $100 \%$ or nearly $100 \%$ (Fig. 11). In contrast, $S^{68}$ was present in $41 \%$, and $\mathrm{S}^{70}$ - in $60 \%$ of the Tat isolates and all other serines were present in less than 50\% (Fig. 11). This analysis indicates that $S^{16}$ and $S^{46}$ residues might be critical for HIV-1 replication. Because $S^{16}$ and $S^{46}$ residues were $100 \%$ conserved, it was not possible to analyze the effect of the mutation of these residues on the HIV-1 progression. We took advantage of the notion that a lysine or arginine present in the fourth position of the (S/ $\mathrm{T})_{0} \mathrm{P}_{1} \mathrm{~K}_{2}(\mathrm{~K} / \mathrm{R})_{3}$ consensus motif is critical for the recognition of the motif by CDK2 $[27,28]$. Thus we analyzed whether $(K / R)^{19}$ and $R^{49}$ residues within ${ }^{16} \mathrm{SQP}(\mathrm{K} / \mathrm{R})^{19}$ and ${ }^{46} \mathrm{SYGR}^{49}$ sequences of Tat were conserved among different HIV-1 isolates and whether mutations in these residues correlated with apparent progression of disease in the patient from whom the isolates were obtained. In this investigation, we studied 105 sequences of Tat deposited to PubMed database [34]. Of these, 55 were obtained 


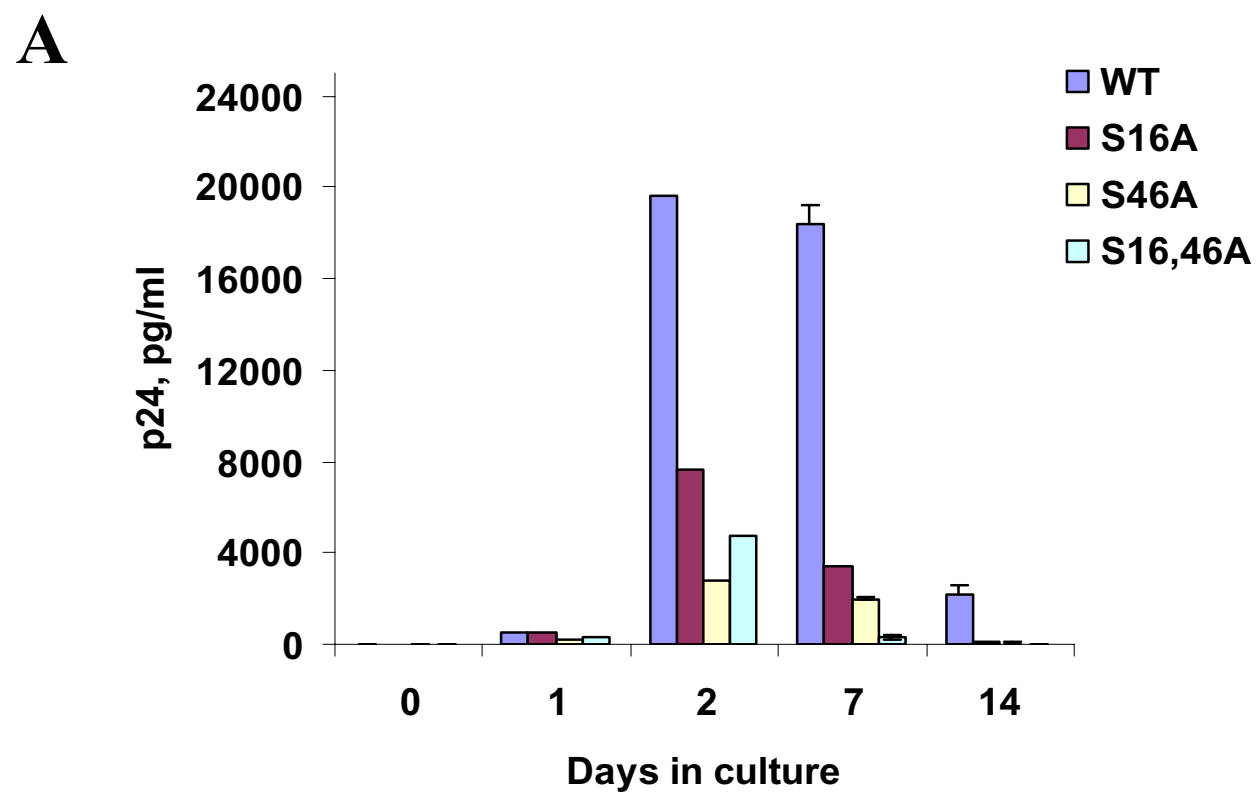

B
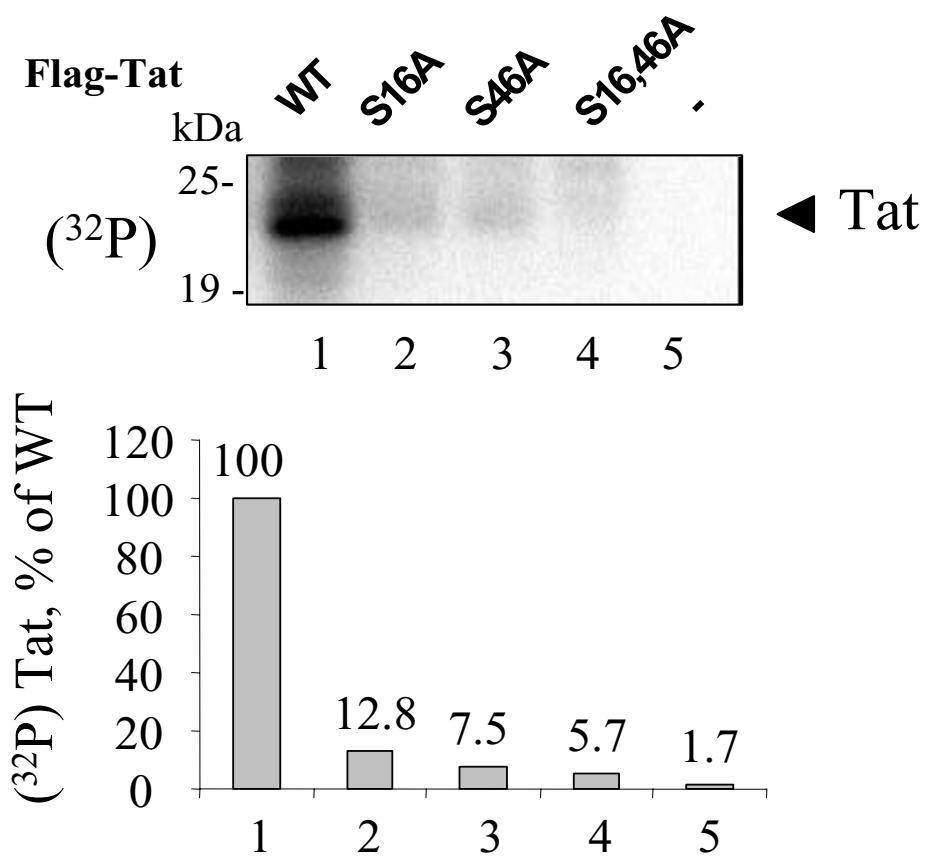

Figure 10

A, Mutations of $\mathbf{S}^{16}$ and $\mathbf{S}^{46}$ of Tat reduce its ability to induce viral production. HLMI is a HeLa derived cells containing one copy of integrated HIV-I proviral genome with a Tat-defective mutation. Various Flag-tagged Tat (WT Tat, Tat SI6A, Tat S46A or Tat S16,46A) expression vectors were used for HLM-I transfections. Cells were cultured in complete media in absence of G4I8 for 14 days. The supernatants were collected at Day 0, I, 2, 7 and I4, and analyzed for p24 by ELISA assay. B, Mutations of $\mathbf{S}^{16}$ and $\mathbf{S}^{46}$ of Tat inhibit Tat phosphorylation during one round of viral replication. HLMI cells were transfected with vectors expressing Flag-tagged Tat (WT Tat, Tat SI6A, Tat S46A or Tat SI6,46A). At 48 hours post transfection the cells were labeled with (32P)-orthophosphate for 2 hours with I $\mu$ M okadaic acid. Flag-Tat was immunoprecipitated from whole cell extracts with anti-Flag antibodies and resolved by 15\% Tris-Tricine SDS-PAGE. The gel was dried and exposed to Phosphor Imager screen. Lane I, Wt Tat. Lane 2, Tat SI6A. Lane 3, Tat S46A. Lane 4, Tat SI6,46A. Lane 5, mock-transfected cells. The picture is an autoradiogram. 
from patients who were not on antiretroviral treatment and were classified as being healthy, and 50 were from patients who were classified as being ill and who were on antiretroviral treatment. We found that $\mathrm{R}^{49}$ was absolutely conserved, and thus no correlation could be obtained. In contrast, Table 2 shows that 29 (53\%) of the "healthy" HIV patients had a (K/R) ${ }^{19}$ mutation compared to only 4 $(8 \%)$ of the "ill" HIV patients (Pearson Chi-square correlation 24.312, $\mathrm{df}=1 ; \mathrm{P}<0.001)$. This result suggests physiological importance of mutation of position 19 of Tat for progression of HIV-1 disease, and are consistent with the possibility that ${ }^{16} \mathrm{SQP}(\mathrm{K} / \mathrm{R})^{19}$ sequence is a putative CDK2 recognition site in Tat.

\section{Discussion}

Our recent studies indicate that Tat's role in HIV-1 transcription is extremely complex and may not confine solely to the interaction with CDK9/cyclin T1. We have previously reported that Tat interacts directly or indirectly with host cell protein phosphatase 1 (PP1) and protein phosphatase 2A (PP2A). Tat binds to protein phosphatase-1 (PP1) and this binding is important for the induction of HIV-1 transcription by Tat $[31,35]$. Tat interaction with PP1 is intriguing as PP1 regulates CDK9 phosphorylation in vivo [36]. We recently showed that Tat binds to LIS1 protein, a product of lissencephaly gene which mutations cause a severe brain malformation [37]. LIS1 resembles the B-subunit of PP2A and interacts with the catalytic subunit of PP2A; and LIS1 expression induces HIV-1 transcription [38]. Thus Tat might also be able to interact with PP2A, although not directly with its catalytic subunit. The current study adds more complexity to the Tat function showing that Tat might undergo phosphorylation by CDK2/cyclin E.

We hypothesized here that CDK2 affects HIV-1 transcription by phosphorylating Tat and that Tat phosphorylation might be important for HIV-1 transcription. We show here that Tat undergoes phosphorylation in vivo on serine residues, and that CDK2 is involved in this phosphorylation. Our findings also indicate that phosphorylation of Tat is important for HIV-1 transcription and the activation of integrated HIV-1 provirus. In our previous work we demonstrated that CDK2/cyclin E phosphorylates the Cterminal domain of RNA polymerase II in vitro [39-41]; that CDK2 was required for Tat-dependent transcription in vitro, and that CDK2 phosphorylates HIV-1 Tat in vitro
[20,41]. CYC202 (R-roscovitine), a pharmacological inhibitor of CDK2, efficiently inhibited replication of wild type and HAART resistant HIV-1 mutants in T-cells, monocytes and PBMCs [42] indicating that CDK2 activity is required for HIV-1 replication. Recently we showed that siRNA-directed against CDK2 inhibits Tat-induced HIV-1 transcription and HIV-1 viral replication [33]. Thus our present study as well as our previous studies point to CDK2 as an important regulator of HIV-1 transcription. Until recently CDK2/cyclin E was considered to be essential for cell cycle progression and that CDK2 regulates G1/ $\mathrm{S}$ transition by phosphorylating Rb-sequestering factors, including E2F [43]. Recent findings challenged this role of CDK2. CDK2 knock-out mice were viable [44], suggesting that CDK2 is dispensable for proliferation and survival of most cell types. Also, inhibition of CDK2 activity through expression of p27 Kip1, dominant-negative CDK2, antisense oligonucleotides or siRNA did not have an effect on growth of several tumor cell lines [45]. Therefore, not being essential for cellular viability, CDK2 might present a feasible target for anti-HIV-1 therapeutics.

Previous attempts to detect Tat phosphorylation in vivo were not successful [25]. It is possible that low level of Tat expression or fast dephosphorylation in the cells or during sample preparation may not allow easy detection of Tat phosphorylation. For example, in the early studies Ben Berkhout and his colleagues could only detect Tat expression in COS-7 cells but not in HeLa cells [46-48]. We found that expression of Flag-tagged Tat allowed higher levels of Tat expression especially with the adeno-virus mediated delivery. Treatment with okadaic acid, which inhibits phosphatases of the PPP-family including PP1 and PP2A [49], significantly enhanced Tat phosphorylation (Fig. 3), suggesting that Tat may be dynamically dephosphorylated by a cellular PPP-type phosphatase. When we inhibited PP1 by over expression of the central domain of nuclear inhibitor of PP1 (NIPP1) [31] we did not detect changes in Tat phosphorylation (data not shown). Thus PP2A rather than PP1 is a candidate phosphatase to dephosphorylate Tat.

Our analysis showed that inhibition of CDK2 expression by siRNA substantially blocked Tat phosphorylation and prevented association of Tat with CDK2. Although these findings suggest that CDK2 might directly phosphorylate Tat, we also cannot rule out a possibility that inhibition of

Table 2: Mutation of $(K / R)^{19}$ residue sequence of Tat and Sickness Status

\begin{tabular}{lccc}
\hline & Healthy & Sick & Total \\
\hline Non-mutated Tat (K/R)/9 & 26 & 46 & 72 \\
Tat (K/R)I9(T, A or G) & 29 & 4 & 33 \\
Total & 55 & 50 & 105 \\
\hline
\end{tabular}




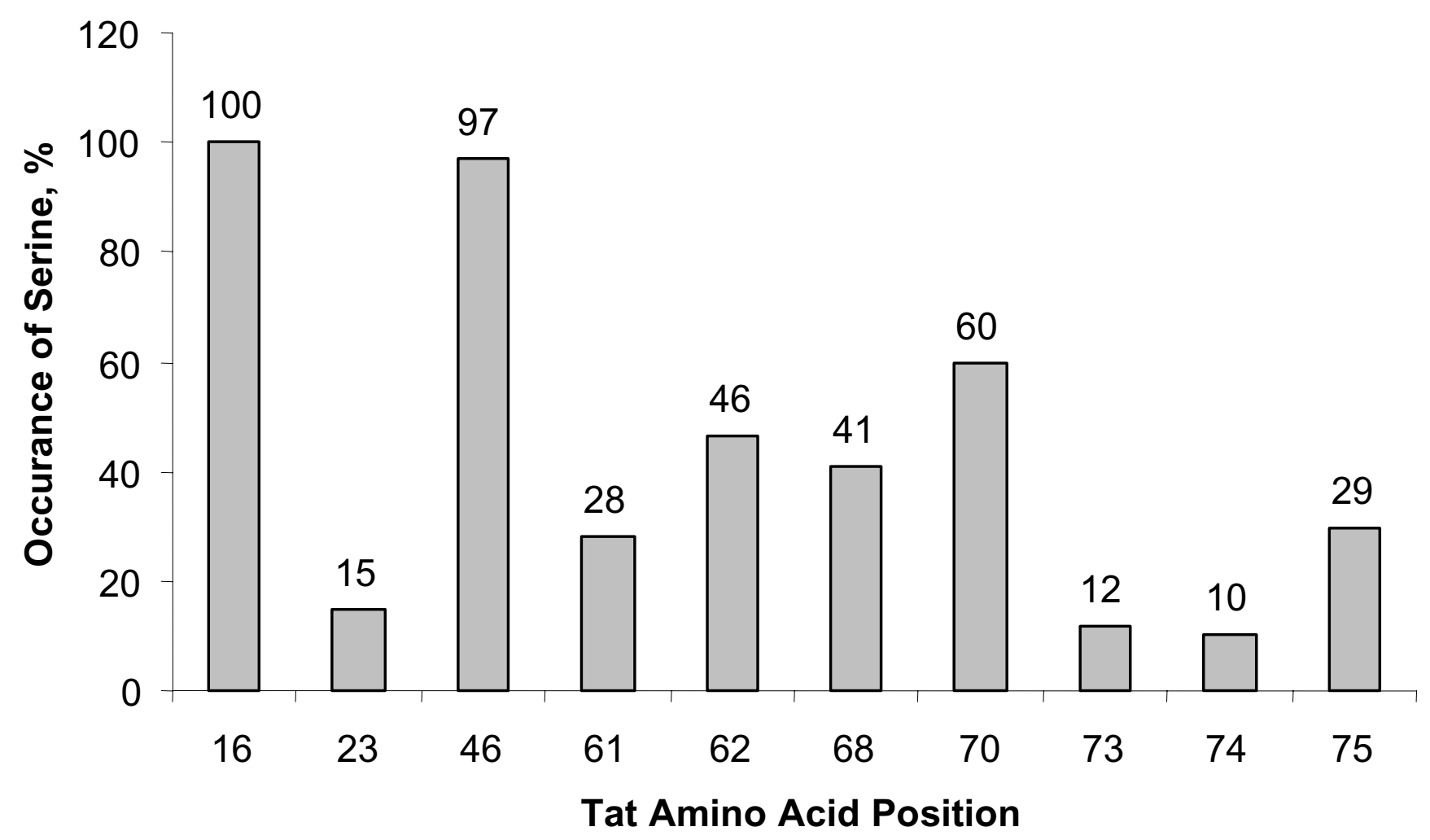

Figure I I

Serine residues at position 16 and 46 are highly conserved in Tat isolates. The 158 sequences of Tat isolates deposited to PubMed database were analyzed for the presence of serines at position $16,23,46,61,68,70,73,74$ and 75 . Presence of a serine at the indicated position is presented as a percent of the total number of the isolates analyzed.

CDK2 reduces the activity of another kinase that in turn might be involved in Tat phosphorylation. Finding that Tat co-migrates with CDK2 on glycerol gradient and also co-precipitated with CDK2 confirms our previous observation that Tat-associated kinase activity contained CDK2 [41]. CDK2-directed siRNA significantly reduced association of CDK2 to Tat, probably by reducing the amount of CDK2 available to interact with Tat.

We found that Tat is phosphorylated on serine residues in vivo. We previously suggested that the ${ }^{16} \mathrm{SQPK}^{19}$ and $\mathrm{K}^{41} \times$ $\mathrm{L}^{43}$ sequences of Tat interact with CDK2 and cyclin E respectively, and that S16 is phosphorylated by CDK2 [20]. In the present study we found that both $S^{16}$ and $S^{46}$ of Tat are potential phosphorylation sites. As $S^{46}$ is adjacent to the $\mathrm{K}^{41} \times \mathrm{L}^{43}$ sequence of Tat, it is likely that the $\mathrm{K}^{41}$ $\times \mathrm{L}^{43}$ sequence participates in binding to CDK2 rather than to cyclin E, as we originally suggested. Interestingly, recombinant $\mathrm{CDK} 2 /$ cyclin $\mathrm{E}$ only phosphorylated full length Tat 1-72 but not the 15 amino acid peptides of Tat, ${ }^{9}$ EPWKHPGSQPKTACN ${ }^{23}$ or ${ }^{37}$ CFTTKGLGISYGRKK ${ }^{51}$ (AIDS Research and Reference Reagents Program, NIH), containing only the phosphorylation sites (data not shown), which may indicate a requirement of additional sequences of Tat for its interaction with CDK2/cycline E. Another explanation is that full length Tat creates a favorable conformation for phosphorylation by CDK2. The sequences ${ }^{16} \mathrm{SQP}(\mathrm{K} / \mathrm{R})^{19}$ and ${ }^{46} \mathrm{SYGR}^{49}$ only partially match the CDK2 $(\mathrm{S} / \mathrm{T})_{0} \mathrm{P}_{1} \mathrm{~K}_{2}(\mathrm{~K} / \mathrm{R})_{3}$ phosphorylation motif. Although the catalytic efficiency of CDK2-cyclin A is impaired 2000-fold, when Pro $_{1}$ is substituted with Ala in a short synthetic peptide substrate, physiological substrates for both CDK2-cyclin A and CDK2-cyclin E often contain phosphorylation motifs replaced with sub optimal determinants [28]. In such sub optimal substrates phosphorylation is enhanced by a cyclin-binding motif that compensates for otherwise poor catalysis [28]. Therefore, binding of cyclin E still might be important for efficient phosphorylation of Tat by CDK2.

Using mutation analysis, we found that $S^{16}$ and $S^{46}$ are equally important for activation of integrated proviral DNA. The single point mutants did not show a significant level of activation, and the double mutant Tat was completely inactive in HLM-1 cells. In contrast, mutation of $\mathrm{S}^{16}$ and $\mathrm{S}^{46}$ moderately reduced activation of HIV-1 tran- 
scription from the episomal promoter. Thus Tat $S^{16}$ and $S^{46}$ residues are important for transcription of a full genomic HIV-1 template containing natural chromatin structure. The effect of alanine mutation of $S^{46}$ is at variance with the previously published observation that alanine mutation of $S^{46}$ induces Tat-transactivation [50]. We did not see an increase of Tat transactivation with all mutants tested. Thus we cannot explain this discrepancy. Tat was proposed to form aggregates in the nucleus [51]. Using yeast two-hybrid system, we found no evidence that Tat forms dimers in yeast cells (not shown). Therefore, it remains to be determined why Tat should undergo phosphorylation to be fully active as a transcriptional activator. We did not detect a difference between WT and mutant Tat in ability to bind to TAR RNA (not shown). We observed an increase in the expression of untagged Tat with mutations in the $\mathrm{S}^{16}$ or $\mathrm{Ser}^{46}$ Tat residues and particular of the double mutant of Tat (Fig. 8A). An increase in Tat expression was observed earlier by Rice and Carlotti with a mutant of Tat that lacked first $36 \mathrm{~N}$-terminal amino acids [50]. Thus the amount of Tat expressed in the cells might be stringently controlled and the excess of Tat might have a negative effect on Tat transactivation. Another possibility is that Tat may need to undergo nonproteolytic ubiquitination by $\mathrm{Hdm} 2$ ubiquitin ligase [22] to be fully active as a transactivator. It is possible that Tat phosphorylation may facilitate ubiquitination of Tat by Hdm2 similar to phosphorylation-dependent ubiquitination of p53 by Hdm2 [52].

Analysis of Tat sequences available in the PubMed showed that Tat isolates contain from 4 to 11 serine residues. In addition to the highly conserved $S^{16}$ and $S^{46}$ residues, Tat contains less conserved serines at positions 23, $61,62,68,70,73,74$ and 75 . Analysis of the ${ }^{16} \mathrm{SQP}(\mathrm{K} /$ R) ${ }^{19}$ and ${ }^{46}$ SYGR $^{49}$ sequences of Tat, showed that $\mathrm{R}^{49}$ is conserved among different HIV-1 isolates. Interestingly, mutations in the $(\mathrm{K} / \mathrm{R})^{19}$ residue showed correlation with non-progression of HIV-1 disease. Thus (K/R $)^{19}$ residue which is part of a putative CDK2 recognition site in Tat, may be important for progression of HIV-1 disease. Future study will address whether mutation of $(K / R)^{19}$ residue is important for phosphorylation of Tat by CDK2 and whether mutations in this residue affect viral replication.

Taken together, our findings indicate that Tat is phosphorylated in vivo and that phosphorylation of Tat is important for the activation of integrated HIV-1 provirus. Our finding also indicates that CDK2 associates with Tat and thus is likely to phosphorylate Tat directly in vivo. Our findings open the door to the evaluation of the potential efficiency of presently available CDK2 inhibitors and specifically designed future inhibitors to disrupt CDK2-Tat association.

\section{Methods \\ Materials}

293 T cells and COS-7 cells were purchased from ATCC (Manassas, VA). HeLa-MAGI cells [53], HLM-1 cells [54], anti-Tat rabbit polyclonal (HIV-1 BH10 Tat antiserum, [55]) and monoclonal (NT3 2D1.1, courtesy of Dr. Jonathan Karn) antibodies were received from the AIDS Research and Reference Reagents Program (NIH). AntiFlag monoclonal antibodies, anti- $\alpha$-tubulin antibodies, protein (G) and protein (A) agarose and okadaic acid were purchased from Sigma (Atlanta, GA). All radioactive reagents were purchased from GE Health Care Life Sciences. The 3,3'-diaminobenzidine enhanced liquid substrate system for membrane ELISA (DABM) was purchased from Sigma (St Louis, MO). Antibodies for CDK2, CDK9, cyclin $\mathrm{T} 1$ and cyclin $\mathrm{T} 2$ were purchased from Santa Cruz Biotechnology (Santa Cruz, CA). Antibodies against RNAPII were from Babco. Anti-Brd4 and anti-HEXIM1 antibodies were a gift from Dr.Q. Zhou (University of California, Berkeley). HIV-1 Tat was expressed in Escherichia coli and purified on Aquapore RP-300 column (Applied Biosystems, Foster City, CA) by reverse-phase chromatography as we described [20].

\section{Plasmids}

Tat expression plasmid was a gift from Dr. Ben Berkhout (University of Amsterdam) [48]. The Flag-Tat was cloned into the adeno-CMV-link vector as described below and verified by sequencing. The S16A and S46A mutations of the sequence of Tat were made according to the QuickChange site-directed mutagenesis protocol of Stratagene, using the appropriate primers and templates. The sequences of the DNA constructs were verified by sequencing using a commercial service from Macrogen (Seoul, Korea).

\section{CDK2/cyclin E purification}

CDK2 and cyclin E were purified from lysates of Sf9 insect cells infected with baculoviruses producing CDK2 and cyclin E. Proteins were purified essentially as described earlier [56]. Briefly, $1 \mathrm{ml}$ of cells (from $250 \mathrm{ml}$ of culture) was lysed with $16 \mathrm{ml}$ of lysis buffer $(50 \mathrm{mM}$ Tris- $\mathrm{HCl}, \mathrm{pH}$ 8.0, $10 \mathrm{mM}$ 2-mercaptoethanol, 10\% glycerol and with PMSF), homogenized on ice and centrifuged at 45,000 g for $1 \mathrm{hr}$ at $4^{\circ} \mathrm{C}$. Supernatant was loaded on Mono-Q 10/ 10 column (Amersham, USA). Two separate cell cultures, one infected with CDK2-expressing baculovirus and the other one infected with cyclin E-expressing baculovirus were used for purification. The Mono-Q fractions containing CDK2 or cyclin E were mixed 1:1 and loaded onto Superdex column (Sephadex H200, Amersham, USA). Purity of CDK2/cyclin E was checked on 12\% PAGE followed by Coomassie staining (Additional file 1). We also analyzed the Superdex fractions by immunoblotting with andti-CDK2 antibodes and assayed their enzymatic activ- 
ity using histone $\mathrm{H} 1$ and purified Tat proteins as substrates. Fractions containing CDK2/cyclin E were concentrated using Microcon tubes (Amicon, USA).

\section{In vitro kinase assay}

CDK2 kinase assays were performed at $30^{\circ} \mathrm{C}$ for $30 \mathrm{~min}$ in kinase assay buffer (50 mM HEPES-KOH, pH 7.9, 10 $\mathrm{mM} \mathrm{MgCl} 2,6 \mathrm{mM}$ EGTA, $2.5 \mathrm{mM}$ DTT) containing histone $\mathrm{H} 1$ or purified Tat protein, $200 \mu \mathrm{M}$ ATP and $(\gamma$ $\mathrm{P}^{32}$ )ATP. A mixture was incubated for $30 \mathrm{~min}$ at $30^{\circ} \mathrm{C}$, reaction was stopped with $8 \mu$ of $4 \times$ SDS buffer and resolved on $12 \%$ PAGE.

Immunoprecipitation of CDK2 and kinase assay with Tat 293 cells were transfected with CDK2-directed or nontargeting siRNA. At 48 hours after transfection cells were lysed in whole cell lysis buffer. About $50 \mu \mathrm{g}$ of protein lysate was subjected to precipitation with anti-CDK2 rabbit antibodies (600 ng/IP) on $40 \mu \mathrm{l}$ protein A agarose beads (50\% slurry) (Sigma). As a control, rabbit preimmune serum was used. Precipitation was carried out for 2 hrs at $4^{\circ} \mathrm{C}$. The beads were washed with TNN buffer, then with TTK buffer and supplemented with $20 \mu \mathrm{l}$ of kinase mixture containing TTK buffer, $100 \mu \mathrm{M}$ ATP, $0.5 \mu \mathrm{Ci}$ of $\gamma$ (32P)ATP and $1 \mu \mathrm{g}$ of purified Tat. The kinase reaction was carried out for $15 \mathrm{~min}$ at $30^{\circ} \mathrm{C}$, reaction was stopped with $8 \mu \mathrm{l}$ of $4 \times$ SDS-loading buffer and resolved on $12 \%$ TrisTricine gel. The gel was stained with Coomassie blue, dried and exposed to Phosphor Imager screen.

\section{Fractionation of cellular lysates on glycerol gradient}

293 T cells were infected with Adeno-Tat virus with MOI 1, and incubated overnight. The cells in $100 \mathrm{~mm}$ plate were lysed with $0.5 \mathrm{ml}$ of whole cell lysis buffer (50 mM Tris$\mathrm{HCl}, \mathrm{pH} 7.5,0.5 \mathrm{M} \mathrm{NaCl}, 1 \% \mathrm{NP}-40,0.1 \% \mathrm{SDS}$ ) supplemented with protease cocktail (Sigma) and RNasin (Amersham). Cell lysates were clarified by centrifugation for $30 \mathrm{~min}$ at $10,000 \mathrm{~g}$ and loaded on top of $10 \%$ to $30 \%$ glycerol $(9 \mathrm{ml})$ gradient. Glycerol gradient buffer contained 20 mM HEPES-KOH, pH 7.9, 150 mM KCl, 200 $\mu \mathrm{M}$ EDTA

The gradient was spun in SW 41Ti rotor (Beckman) at $38,000 \mathrm{rpm}$ for 18 hours. Fractions $(0.5 \mathrm{ml})$ were collected through a needle inserted to the bottom of the tube and analyzed by Immunoblotting.

\section{Tat trypsinization and chromatographic separation of peptides}

Non-phosphorylated and phosphorylated Tat were resolved by $15 \%$ Tris-Tricine SDS-PAGE. A gel piece containing Tat was crushed and incubated with $1 \mu \mathrm{g}$ of porcine trypsin (Promega, Madison, WI) in $0.1 \mathrm{M} \mathrm{NaHCO}_{3}$ (pH 7.9) overnight at $37^{\circ} \mathrm{C}$. The extracted peptides were lyophilized, dissolved in $0.1 \%$ TCA and separated by reverse-phase chromatography on a $\mu \mathrm{RPC}$ C2/C18 ST 4.6/ 100 column (Amersham Pharmacia Biotech) using AKTA purifier (AmershamPharmaciaBiotech). Eluent A was $0.1 \%$ TCA in water and eluent B was $0.1 \%$ TCA in $90 \%$ acetonitrile. The gradient was $5 \% \mathrm{~B}$ for 2 column volumes (CVs), 5-50\% B for 20 CVs, 50-100\% B for $12 \mathrm{CVs}$ and $100 \% \mathrm{~B}$ for $4 \mathrm{CVs}$. The flow rate was $0.5 \mathrm{ml} / \mathrm{min}$.

\section{MALDI-TOF mass spectrometry and peptide sequencing}

Fractions from the HPLC separation described above were lyophilized. Multiple peptide sequences were determined in a single run by Applied Biosystems Maldi-TOF/TOF 4700 proteomics analyzer $(25-30,000$ resolution in reflectron mode, 5 ppm accuracy with IS, subfmole sensitivity for peptide mass fingerprints (PMF), fmole sensitivity for PSD/CID capacity of >36,000 PMF per 24 hours). Data were analyzed utilizing a local multi-processor installation of MASCOT MS PMF and MS/MS PSD, CID peptide identification software. GPS also supports an integrated MS-MS/MS mode and a chromatographic separation mode with SEQUEST-like capability.

\section{Preparation of Adeno-Tat}

The E1-deleted recombinant Ad carrying Tat was generated as previously described [31]. Briefly, a cDNA fragment encoding the full length HIV-1 Tat protein was cloned into the plasmid pCXN was subcloned in the pAd.CMV link plasmid. The Tat-coding DNA corresponds to the HIV-1 isolate P9.3 from United Kingdom (Accession number AF324447). The DNA sequence is ATGGACTACAAGGACGACGA TGACAAAGAA TTCATGGAGC CAGTAGATCCTAGACTAGAG CCCTGGGAGC ATCCAGGAAG TCAGCCTAAG ACTGCTTGTACCCCTTGCTA TTGTAAAAAG TGTTGCTTTC ATTGCCAAGT TTGTTTCACAACAAAAGGCT TAGGCATCTC CTATGGCAGG AAGAAGCGGA GACAGCGACGAAGAGCTCCT CAAGACAGTC AGACTCATCA GGCTTCTCTA TCAAAGCAATCCCTACCCCA AACCCAGAGG GACTCGACAG GCCCGGAAGA ATCGAAGAAGGAGGTGGAGA GCAAGGCAGAGACAGATCGA TTCGATTA. It corresponds to the protein sequence of Tat containing Flag epitope at its N-terminusMDYKDDDDKEFMEPVDPRLEPWEHPGSQPKTACTPCYCKKCCFHCQVCFTTKGLGISYGRKKRRQRRRAPQDSQTHQASLSKQSLPQTQRDSTGPEESKKEVESKAETDRFD - pAd.CMVlink and Cla I digested adenoviral DNA were co-transfected into HEK293 cells at a ratio of 3:1 by calcium phosphate precipitation to allow the recombination. The virus was purified through three rounds of plaque-purification. Viruses were replicated in HEK293 cells and were purified from a cell lysate by two rounds of $\mathrm{CsCl}$ density gradient centrifugation. The purified virus was desalted on a Bio-Gel P-6 desalting column (Bio-Rad Laboratories, Hercules, CA) equilibrated with PBS. The titer of the virus preparation was determined both by 
absorbency at $260 \mathrm{~nm}$ and by plaque assay. The particle to plaque forming unit ratio was less than 100. Purified viruses were suspended in PBS at the desired concentrations.

\section{Tat phosphorylation in vivo}

HeLa cells were infected with recombinant Adenovirus carrying Flag-tagged Tat prepared as we described [31]. The purified virus had a particle to plaque forming unit (Pfu) ratio of less than 100 . We added approximately 10 Pfu per cell to achieve high level of Tat expression in infected HeLa cells. At 48 hours post infection the media was changed for 1 hour to a phosphate-free DMEM media (Life Technologies, Rockville, MD) containing no serum. Then the media was changed to phosphate-free DMEM supplemented with $0.5 \mathrm{mCi} / \mathrm{ml}$ of (32P)-orthophosphate and cells were further incubated for 2 hours at $37^{\circ} \mathrm{C}$. Where indicated, $1 \mu \mathrm{M}$ okadaic acid (Sigma) was added to block cellular PPP-phosphatases. Cells were washed with PBS and lysed in whole cell lysis buffer $(50 \mathrm{mM}$ Tris- $\mathrm{HCl}$, $\mathrm{pH} 7.5,0.5 \mathrm{M} \mathrm{NaCl}, 1 \% \mathrm{NP}-40,0.1 \%$ SDS) supplemented with protease cocktail (Sigma). After 10 min on ice, cellular material was scraped and then centrifuged at 14,000 $\mathrm{rpm}, 4^{\circ} \mathrm{C}$ for $30 \mathrm{~min}$. The supernatant was recovered and immediately used for immunoprecipitation. Tat was precipitated with anti-Flag monoclonal antibodies coupled to protein $\mathrm{G}$ agarose and with polyclonal anti-Tat antibodies coupled to protein A agarose for $2 \mathrm{~h}$ at $4^{\circ} \mathrm{C}$ in a TNN Buffer containing $50 \mathrm{mM}$ Tris- $\mathrm{HCl}, \mathrm{pH} 7.5,0.15 \mathrm{M}$ $\mathrm{NaCl}$, and $1 \% \mathrm{NP}-40$. The immunoprecipitated Tat was recovered by heating for $2 \mathrm{~min}$ at $100^{\circ} \mathrm{C}$ in Tricine SDSloading buffer, resolved on 15\% Tris-Tricine SDS-PAGE [32] and transferred to polyvinylidene fluoride (PVDF) membranes (Millipore, Allen, TX). The membrane was analyzed with anti-Tat monoclonal antibodies using 3,3'Diaminobenzidine enhancer system (Sigma) and was also exposed to Phosphor Imager screen (Packard Instruments, Wellesley, MA).

\section{Phosphoamino acid analysis}

The analysis was carried out on the Hunter thin layer peptide mapping electrophoresis system (CBS, Del Mar, CA) according to the manufacturer's recommendations. Briefly, phosphorylated Tat, prepared as described above was resolved on 15\% SDS-Tris-Tricine PAGE and the gel was dried on a Whatman paper. The portion of the gel containing Tat was excised, rehydrated and treated overnight with trypsin to elute Tat. The eluted peptides were boiled in $5.7 \mathrm{M} \mathrm{HCl}$ at $110^{\circ} \mathrm{C}$ to liberate (32P)-labeled phospho-amino acids as described [57]. After the hydrolysis, the sample was lyophilized and resuspended in the buffer for $\mathrm{pH} 1.9$ electrophoresis also containing the phosphoamino acid standards at $0.06 \mathrm{mg} / \mathrm{ml}$. The sample was resolved by thin-layer electrophoresis on a cellulose plate (CBS, Del Mar, CA) at $\mathrm{pH} 1.9$ in the first direction and at $\mathrm{pH} 3.5$ in the second direction. Cold standards were visualized by staining the plate with $0.25 \%$ ninhydrine dissolved in ethanol. Positions of labeled phosphoamino acids were analyzed with Phosphor Imager (Packard Instruments, Wellesley, MA).

\section{Transfection and HIV-I detection from HLMI cells}

HLM-1cells were derived from HeLa-T4+ cells integrated with one copy of HIV-1 genome containing a Tat-defective mutation. The mutation was introduced as a triple termination linker (TTL) at the first AUG of Tat gene [54]. HLM1 cells are negative for virus particle production HLM1 cells are negative for virus particle production. HLM1 cells can be induced to express non-infectious HIV-1 particles after transfection with Tat cDNA, or by treatment with mitogens such as TNF- $\alpha$ or sodium butyrate. HLM1 cells were grown in DMEM media containing $100 \mu \mathrm{g} / \mathrm{ml}$ of G418, plus $1 \%$ streptomycin, penicillin antibiotics and 1\% L-Glutamine (Gibco/BRL). The cells grown up to $75 \%$ confluence were transfected with Tat expression vectors, including wild type Tat, S16A, S46A, and S16A/S46A mutant Tat plasmids using the calcium phosphate method. The transfected cells were washed after four hrs and fresh complete DMEM media with $10 \%$ fetal bovine was added for the remainder of the experiment. The p24 gag antigen was detected in the supernatants of transfected cells using a standard ELISA kit (Abbott).

\section{siRNA treatment}

CDK2-directed siRNA pool (M-003236-03-005) and negative control pool (D-001206-13-05) were purchased from Dharmacon (Dallas, TX). The siRNAs were transfected at final concentration of $100 \mathrm{nM}$ using Lipofectamin reagent (Invitrogen) according to the manufacturer's recommendations. The siRNAs were incubated with cells for 2 days before cells were labeled with ${ }^{32} \mathrm{P}$ or lysed for Western blotting analysis.

\section{Competing interests}

The author(s) declare that they have no competing interests.

\section{Authors' contributions}

TA purified recombinant CDK2/cyclin E, performed in vitro Tat phosphorylation, carried out the experiments with the CDK2-directed siRNA, CDK2-Tat precipitation experiments, Western blot analysis of glycerol gradients and also helped with in vivo (32P) phosphorylation experiments and with Tat mutagenesis. RB and ZK carried out experiments with live virus. MJ prepared adeno-Tat virus, helped to analyze the expression of Tat in cultured cells and prepared samples for MALDI-TOF analysis. MJ and $\mathrm{SN}$ were also running glycerol gradients. SC performed statistical analysis of the HIV-1 isolates. EE performed MALDI TOF analysis of Tat peptides. WS, VRG and FK par- 
ticipated in the design and discussion of the study. SN performed in vivo Tat phosphorylation experiments, phosphoaminoacid analysis of Tat and Tat mutagenesis, and also performed general control and coordination of the study. All authors read and approved the manuscript.

\section{Additional material}

\section{Additional File 1}

Purification of CDK2/cyclin E. Mixed mono Q fractions of CDK2 and cyclin E (Mono Q lane) were purified on Superdex column. Fractions 37, $39,41,43$, and 45 were analyzed for the presence of CDK2 and cyclin E by Coumassie staining.

Click here for file

[http://www.biomedcentral.com/content/supplementary/17424690-3-78-S1.pdf]

\section{Acknowledgements}

This work was supported by NIH Grant R2I AI I56973-0 I (to S. N.), by NHLBI Research Grant UHI HL03679 from the National Institutes of Health and The Office of Research on Minority Health. This work was also supported by grant 2 GI 2 RR003048 from the RCMI Program, Division of Research Infrastructure, National Center for Research Resources, NIH (to W.S.) and by NIH grants Al44357, Al43894 to FK, and Research Enhancement Fund (REF, GW) to Akos Vertes and F. Kashanchi. We thank Dr. Eric Eccleston for help with MALDI-TOF. The authors would like to thank members of Dr. Victor Gordeuk's laboratory at the Center for Sickle Cell Disease at Howard University for valuable discussions. We also thank Dr. Ajit Kumar for permission to use Hunter thin layer peptide mapping electrophoresis system. We thank Qiang Zhou (University of California, Berkeley) for the gift of ant-Brd4 and HEXIMI antibodies.

\section{References}

I. Brady J, Kashanchi F: Tat gets the "green" light on transcription initiation. Retrovirology 2005, 2:69.

2. Brigati C, Giacca M, Noonan DM, Albini A: HIV Tat, its TARgets and the control of viral gene expression. FEMS Microbiol Lett 2003, 220:57-65.

3. Coadou G, Gharbi-Benarous J, Megy S, Bertho G, Evrard-Todeschi N, Segeral E, Benarous R, Girault JP: NMR studies of the phosphorylation motif of the HIV-I protein Vpu bound to the F-box protein beta-TrCP. Biochemistry 2003, 42:|474|-|475|.

4. Agostini I, Popov S, Hao T, Li JH, Dubrovsky L, Chaika O, Chaika N, Lewis R, Bukrinsky M: Phosphorylation of Vpr regulates HIV type I nuclear import and macrophage infection. AIDS Res Hum Retroviruses 2002, 18:283-288.

5. Yang X, Gabuzda D: Mitogen-activated protein kinase phosphorylates and regulates the HIV-I Vif protein. J Biol Chem 1998, 273:29879-29887.

6. Cheng H, Hoxie JP, Parks WP: The conserved core of human immunodeficiency virus type I Nef is essential for association with Lck and for enhanced viral replication in T-lymphocytes. Virology 1999, 264:5-15.

7. Fouts DE, True HL, Cengel KA, Celander DW: Site-specific phosphorylation of the human immunodeficiency virus type- 1 Rev protein accelerates formation of an efficient RNA-binding conformation. Biochemistry 1997, 36:13256-13262.

8. Kim YK, Bourgeois CF, Isel C, Churcher MJ, Karn J: Phosphorylation of the RNA polymerase II carboxyl-terminal domain by CDK9 is directly responsible for human immunodeficiency virus type I Tat-activated transcriptional elongation. Mol Cell Biol 2002, 22:4622-4637.

9. Zhu Y, Pe'ery T, Peng J, Ramanathan Y, Marshall N, Marshall T, Amendt B, Mathews MB, Price DH: Transcription elongation fac- tor P-TEFb is required for HIV-I tat transactivation in vitro. Genes Dev 1997, I I:2622-2632.

10. Raha T, Cheng SW, Green MR: HIV-I Tat stimulates transcription complex assembly through recruitment of TBP in the absence of TAFs. PLoS Biol 2005, 3:e44.

II. Jeang KT, Berkhout B, Dropulic B: Effects of integration and replication on transcription of the HIV-I long terminal repeat. J Biol Chem 1993, 268:24940-24949.

12. Jeang KT, Berkhout $B$ : Kinetics of HIV-I long terminal repeat trans-activation. Use of intragenic ribozyme to assess ratelimiting steps. J Biol Chem 1992, 267:1789|-17899.

13. Kashanchi F, Piras G, Radonovich MF, Duvall JF, Fattaey A, Chiang CM, Roeder RG, Brady JN: Direct interaction of human TFIID with the HIV-I transactivator tat. Nature 1994, 367:295-299.

14. Herrmann $\mathrm{CH}$, Rice AP: Lentivirus Tat proteins specifically associate with a cellular protein kinase, TAK, that hyperphosphorylates the carboxyl-terminal domain of the large subunit of RNA polymerase II: candidate for a Tat cofactor. J Virol 1995, 69:1612-1620.

15. Yang X, Gold MO, Tang DN, Lewis DE, Aguilar-Cordova E, Rice AP, Herrmann $\mathrm{CH}$ : TAK, an HIV Tat-associated kinase, is a member of the cyclin-dependent family of protein kinases and is induced by activation of peripheral blood lymphocytes and differentiation of promonocytic cell lines. Proc Natl Acad Sci U SA 1997, 94:12331-12336.

16. Kiernan RE, Vanhulle C, Schiltz L, Adam E, Xiao H, Maudoux F, Calomme C, Burny A, Nakatani Y, Jeang KT, Benkirane M, Van Lint C: HIV-I tat transcriptional activity is regulated by acetylation. Embo J 1999, 18:6106-61/8.

17. Ott M, Schnolzer M, Garnica J, Fischle W, Emiliani S, Rackwitz HR, Verdin E: Acetylation of the HIV-I Tat protein by p300 is important for its transcriptional activity. Curr Biol 1999 , 9:1489-1492.

18. Deng L, de la Fuente C, Fu P, Wang L, Donnelly R, Wade JD, Lambert P, Li H, Lee CG, Kashanchi F: Acetylation of HIV-I Tat by CBPI P300 increases transcription of integrated HIV-I genome and enhances binding to core histones. Virology 2000, 277:278-295.

19. Cujec TP, Okamoto H, Fujinaga K, Meyer J, Chamberlin H, Morgan DO, Peterlin BM: The HIV transactivator TAT binds to the CDK-activating kinase and activates the phosphorylation of the carboxy-terminal domain of RNA polymerase II. Genes Dev 1997, I I:2645-2657.

20. Deng L, Ammosova T, Pumfery A, Kashanchi F, Nekhai S: HIV-I Tat interaction with RNA polymerase II C-terminal domain (CTD) and a dynamic association with CDK2 induce CTD phosphorylation and transcription from HIV-I promoter. J Biol Chem 2002, 277:33922-33929.

2I. Bres V, Tagami H, Peloponese JM, Loret E, Jeang KT, Nakatani Y, Emiliani S, Benkirane M, Kiernan RE: Differential acetylation of Tat coordinates its interaction with the co-activators cyclin $\mathrm{TI}$ and PCAF. Embo J 2002, $21: 681 \mathrm{I}-6819$.

22. Bres V, Kiernan RE, Linares LK, Chable-Bessia C, Plechakova O, Treand C, Emiliani S, Peloponese JM, Jeang KT, Coux O, Scheffner M, Benkirane M: A non-proteolytic role for ubiquitin in Tat-mediated transactivation of the HIV-I promoter. Nat Cell Biol 2003, 5:754-76I.

23. Boulanger MC, Liang C, Russell RS, Lin R, Bedford MT, Wainberg MA, Richard S: Methylation of Tat by PRMT6 regulates human immunodeficiency virus type I gene expression. J Virol 2005, 79: $|24-| 3 \mid$.

24. Brand SR, Kobayashi R, Mathews MB: The Tat protein of human immunodeficiency virus type $I$ is a substrate and inhibitor of the interferon-induced, virally activated protein kinase, PKR. J Biol Chem 1997, 272:8388-8395.

25. Hauber J, Bouvier M, Malim MH, Cullen BR: Phosphorylation of the rev gene product of human immunodeficiency virus type I. J Virol 1988, 62:480 I-4804.

26. Herrmann $\mathrm{CH}$, Rice AP: Specific interaction of the human immunodeficiency virus Tat proteins with a cellular protein kinase. Virology 1993, 197:60I-608.

27. Koepp DM, Schaefer LK, Ye X, Keyomarsi K, Chu C, Harper JW, Elledge SJ: Phosphorylation-dependent ubiquitination of cyclin $E$ by the SCFFbw7 ubiquitin ligase. Science 200I, 294: I73-I77. 
28. Stevenson-Lindert LM, Fowler P, Lew J: Substrate specificity of CDK2-cyclin A. What is optimal? J Biol Chem 2003, 278:50956-50960.

29. http://us.expasy.org/tools/findpept.html: .

30. Bennett KL, Stensballe A, Podtelejnikov AV, Moniatte M, Jensen ON Phosphopeptide detection and sequencing by matrixassisted laser desorption/ionization quadrupole time-offlight tandem mass spectrometry. J Mass Spectrom 2002, 37:179-190.

31. Ammosova T, Jerebtsova M, Beullens M, Voloshin $Y$, Ray PE, Kumar $A$, Bollen M, Nekhai S: Nuclear protein phosphatase-I regulates HIV-I transcription. J Biol Chem 2003, 278:32 I89-32194.

32. Schagger $H$, Bentlage $H$, Ruitenbeek W, Pfeiffer K, Rotter S, Rother C, Bottcher-Purkl A, Lodemann E: Electrophoretic separation of multiprotein complexes from blood platelets and cell lines: technique for the analysis of diseases with defects in oxidative phosphorylation. Electrophoresis 1996, 17:709-7|4.

33. Ammosova T, Berro R, Kashanchi F, Nekhai S: RNA interference directed to CDK2 inhibits HIV-I transcription. Virology 2005, $341: 17 \mid-178$.

34. http://www.ncbi.nlm.nih.gov/entrez: .

35. Ammosova $T$, Jerebtsova $M$, Beullens $M$, Lesage $B$, Jackson $A$, Kashanchi F, Southerland W, Gordeuk VR, Bollen M, Nekhai S: Nuclear targeting of protein phosphatase-I by HIV-I TAT protein. J Biol Chem 2005.

36. Ammosova T, Washington K, Debebe Z, Brady J, Nekhai S: Dephosphorylation of CDK9 by protein phosphatase $2 A$ and protein phosphatase-I in Tat-activated HIV-I transcription. Retrovirology 2005, 2:47.

37. Epie N, Ammosova T, Sapir T, Voloshin Y, Lane WS, Turner W, Reiner O, Nekhai S: HIV-I Tat interacts with LISI protein. Retrovirology 2005, 2:6.

38. Epie N, Ammosova T, Turner W, Nekhai S: Inhibition of PP2A by LISI increases HIV-I gene expression. Retrovirology 2006, 3:65.

39. Nekhai S, Shukla RR, Kumar A: A human primary T-lymphocytederived human immunodeficiency virus type I Tat-associated kinase phosphorylates the C-terminal domain of RNA polymerase II and induces CAK activity. I Virol 1997, 71:7436-7441.

40. Nekhai S, Shukla RR, Fernandez A, Kumar A, Lamb NJ: Cell cycledependent stimulation of the HIV-I promoter by Tat-associated CAK activator. Virology 2000, 266:246-256.

4I. Nekhai S, Zhou M, Fernandez A, Lane WS, Lamb NJ, Brady J, Kumar A: HIV-I Tat-associated RNA polymerase C-terminal domain kinase, CDK2, phosphorylates CDK7 and stimulates Tat-mediated transcription. Biochem J 2002, 364:649-657.

42. Agbottah E, de la Fuente C, Nekhai S, Barnett A, Gianella-Borradori A, Pumfery A, Kashanchi F: Antiviral activity of CYC202 in HIVI infected cells. J Biol Chem 2004.

43. Reed SI: Control of the GI/S transition. Cancer Surv 1997, 29:7-23.

44. Malumbres M, Hunt SL, Sotillo R, Martin J, Odajima J, Martin A, Dubus $\mathrm{P}$, Ortega $\mathrm{S}$, Barbacid M: Driving the cell cycle to cancer. Adv Exp Med Biol 2003, 532: I-II.

45. Tetsu O, McCormick F: Proliferation of cancer cells despite CDK2 inhibition. Cancer Cell 2003, 3:233-245.

46. Verhoef K, Koper M, Berkhout B: Determination of the minimal amount of Tat activity required for human immunodeficiency virus type I replication. Virology 1997, 237:228-236.

47. Verhoef K, Bauer M, Meyerhans A, Berkhout B: On the role of the second coding exon of the HIV-I Tat protein in virus replication and MHC class I downregulation. AIDS Res Hum Retroviruses 1998, I4:1553-1559.

48. Verhoef $K$, Berkhout $B$ : A second-site mutation that restores replication of a Tat-defective human immunodeficiency virus. J Virol 1999, 73:278I-2789.

49. Fernandez J], Candenas ML, Souto ML, Trujillo MM, Norte M: Okadaic acid, useful tool for studying cellular processes. Curr Med Chem 2002, 9:229-262.

50. Rice AP, Carlotti F: Mutational analysis of the conserved cysteine-rich region of the human immunodeficiency virus type I Tat protein. J Virol 1990, 64: I864-I868.

5I. Bogerd HP, Fridell RA, Blair WS, Cullen BR: Genetic evidence that the Tat proteins of human immunodeficiency virus types $I$ and $\mathbf{2}$ can multimerize in the eukaryotic cell nucleus. I Virol 1993, 67:5030-5034.
52. Chernov MV, Bean LJ, Lerner N, Stark GR: Regulation of ubiquitination and degradation of $\mathrm{p} 53$ in unstressed cells through $C$ terminal phosphorylation. J Biol Chem 200I, 276:3I8I9-3I824.

53. Kimpton J, Emerman M: Detection of replication-competent and pseudotyped human immunodeficiency virus with a sensitive cell line on the basis of activation of an integrated betagalactosidase gene. J Virol 1992, 66:2232-2239.

54. Sadaie MR, Hager GL: Induction of developmentally programmed cell death and activation of HIV by sodium butyrate. Virology 1994, 202:5I3-5I8.

55. Hauber J, Perkins A, Heimer EP, Cullen BR: Trans-activation of human immunodeficiency virus gene expression is mediated by nuclear events. Proc Natl Acad Sci U S A 1987, 84:6364-6368.

56. Rosenblatt J, De Bondt H, Jancarik J, Morgan DO, Kim SH: Purification and crystallization of human cyclin-dependent kinase 2. J Mol Biol 1993, 230:1317-1319.

57. Cooper JA, Sefton BM, Hunter T: Detection and quantification of phosphotyrosine in proteins. Methods Enzymol 1983, 99:387-402.
Publish with Bio Med Central and every scientist can read your work free of charge

"BioMed Central will be the most significant development for disseminating the results of biomedical research in our lifetime. "

Sir Paul Nurse, Cancer Research UK

Your research papers will be:

- available free of charge to the entire biomedical community

- peer reviewed and published immediately upon acceptance

- cited in PubMed and archived on PubMed Central

- yours - you keep the copyright

Submit your manuscript here:

http://www.biomedcentral.com/info/publishing_adv.asp
BiolMedcentral 